\title{
FY 1995 Remedial Investigation Work Plan for Waste Area Grouping 2 at Oak Ridge National Laboratory, Oak Ridge, Tennessee
}

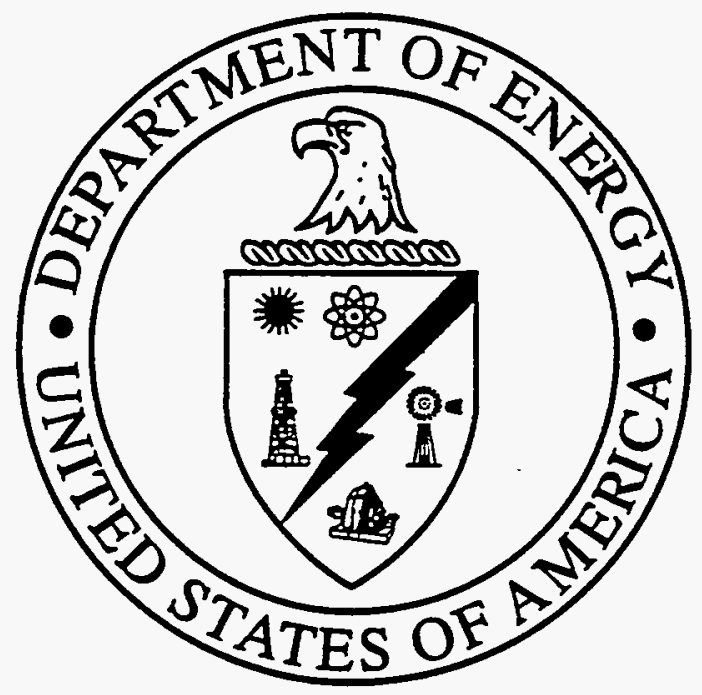




\section{DISCLAIMER}

Portions of this document may be illegible in electronic image products. Images are produced from the best available original document. 
Energy Systems Environmental Restoration Program ORNL Environmental Restoration Program

\title{
FY 1995 Remedial Investigation Work Plan for Waste Area Grouping 2 at Oak Ridge National Laboratory, Oak Ridge, Tennessee
}

\author{
D. R. Watkins and S. E. Herbes, Editors
}

Date Issued-September 1994

Prepared by

Environmental Sciences Division

Oak Ridge National Laboratory

ESD Publication 4302

Prepared for

U.S. Department of Energy

Office of Environmental Management

under budget and reporting code EW 20

Environmental Restoration and Waste Management Programs

Oak Ridge National Laboratory

Oak Ridge, Tennessee 37831-6285

managed by

MARTIN MARIETTA ENERGY SYSTEMS, INC.

for the

U.S. DEPARTMENT OF ENERGY

under contract DE-AC05-84OR21400 


\section{Contributors}

T. L. Ashwood

D. S. Hicks

L. A. Baron

R. H. Ketelle

D. M. Borders

S. T. Purucker

B. B. Burgoa

B. E. Sample

R. B. Clapp

G. W. Suter

S. E. Herbes

D. R. Watkins

\section{Contributor Affiliations}

T. L. Ashwood, R. B. Clapp, S. E. Herbes, D. S. Hicks, B. E. Sample, G. W. Suter, and D. R. Watkins are members of the Environmental Sciences Division (ESD), Oak Ridge National Laboratory (ORNL), managed by Martin Marietta Energy Systems, Inc.; and R. H. Ketelle is affiliated with the Energy Division, ORNL. L. A. Baron is with Jaycor, Oak Ridge. D. M. Borders is a research associate in the Department of Civil and Environmental Engineering, The University of Tennessee, Knoxville (UTK). B. B. Burgoa is a research associate and T. B. Coffey is with the Plant and Soil Science Department, UTK. S. $T$. Purucker is a research associate in the Graduate School of Library and Information Sciences, UTK.

\section{Acknowledgments}

Special thanks are reserved for D. M. Carden at the DOE Environmental Restoration Division, H. L. Boston and the staff at the ORNL Environmental Restoration Program Site Office, and for S. Y. Lee and R. J. Luxmoore of ESD for timely review of this document and their very helpful comments. Special thanks also go to A. L. Harkey and the staff in Information Management Services at ORNL for technical editing, R. F. Winterfield and T. B. Coffey for preparation of figures, and $\mathrm{K}$. $Y$. Smith of ESD for dedicated assistance in preparation of this document. R. F. Winterfield is with the Energy, Environment, and Resources Center, UTK. 


\section{CONTENTS}

FIGURES $\ldots \ldots \ldots \ldots \ldots \ldots \ldots \ldots \ldots \ldots \ldots \ldots \ldots \ldots \ldots \ldots \ldots$

TABLES $\ldots \ldots \ldots \ldots \ldots \ldots \ldots \ldots \ldots \ldots \ldots \ldots \ldots \ldots \ldots \ldots \ldots \ldots \ldots \ldots \ldots \ldots$

ABBREVIATIONS $\ldots \ldots \ldots \ldots \ldots \ldots \ldots \ldots \ldots \ldots \ldots \ldots \ldots \ldots \ldots$ vii

EXECUTIVE SUMMARY $\ldots \ldots \ldots \ldots \ldots \ldots \ldots \ldots \ldots \ldots \ldots \ldots \ldots \ldots$

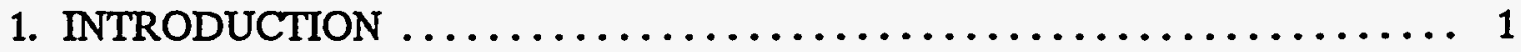

1.1 PURPOSE AND PROJECT SCOPE ................... 1

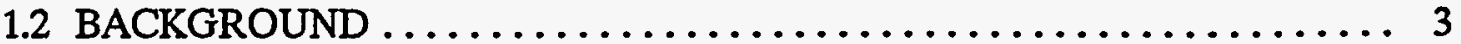

1.3 DATA QUALITY OBJECTIVES WORKSHOP .............. 4

1.3.1 Phase I Decisions . . . . . . . . . . . . . . . . . . . . 5

1.3.2 Phase II Decisions $\ldots \ldots \ldots \ldots \ldots \ldots \ldots \ldots \ldots \ldots \ldots \ldots \ldots$

2. REMEDIAL INVESTIGATION ACTIVITIES FOR WAG 2 IN FY $1995 \ldots \ldots \ldots 8$

2.1 CONCEPTUAL MODEL FOR WAG $2 \ldots \ldots \ldots \ldots \ldots \ldots \ldots \ldots$

2.2 CURRENT UNDERSTANDING OF WAG $2 \ldots \ldots \ldots \ldots \ldots \ldots \ldots$

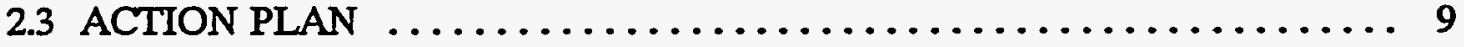

2.4 COMPONENTS OF PROJECT FOR FY $1995 \ldots \ldots \ldots \ldots \ldots \ldots \ldots \ldots \ldots$.

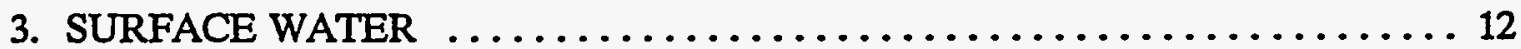

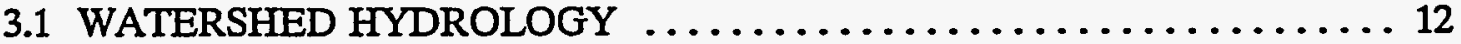

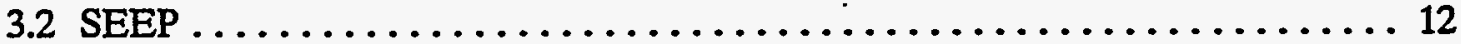

3.3 TRIBUTARY ASSESSMENT $\ldots \ldots \ldots \ldots \ldots \ldots \ldots \ldots \ldots \ldots \ldots \ldots \ldots \ldots$

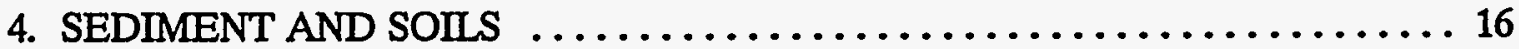

4.1 SEDIMENT AND SOIL CHARACTERIZATION TASK . . . . . . . . 16

4.1.1 Soil Characterization Assessment Subtask . . . . . . . . . . . . . 16

4.1.2 IHP Site Radionuclide Inventory Subtask . . . . . . . . . . . . 16

4.1.3 Bathymetry of White Oak Lake Subtask . . . . . . . . . . . . 16

4.1.4 White Oak Lake Coring Subtask ................... 18

4.1 .5 QA/QC Requirements ............................. 18

4.1.6 Erosion Rates Subtask ............................ 19

4.2 SEDIMENT TRANSPORT MODELING TASK $\ldots \ldots \ldots \ldots \ldots \ldots \ldots \ldots$

4.2.1 Sediment Transport Simulation Subtask .................. 21

4.2.2 Sediment Transport Data Package Subtask ................. 22

4.2.3 Sediment Transport Storm Sampling Subtask . . . . . . . . . . . . . 22

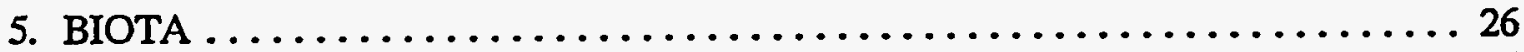

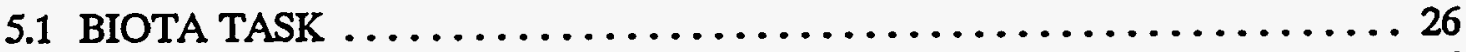

5.1 .1 Mink and Kingfisher Monitoring Subtask ............... 26

5.1 .2 Soil Toxicity Testing Subtask ...................... 27

5.1 .3 Sediment Toxicity Testing Subtask $\ldots \ldots \ldots \ldots \ldots \ldots \ldots \ldots$ 
5.1.4 Earthworm Sampling and Analysis Subtask ... . . . . . . . . . . 29

5.1.5 Shrew Sampling and Analysis Subtask . . . . . . . . . . . . . 30

5.1.6 Benthic Invertebrate Sampling Subtask . . . . . . . . . . . . . 30

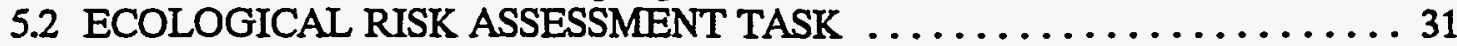

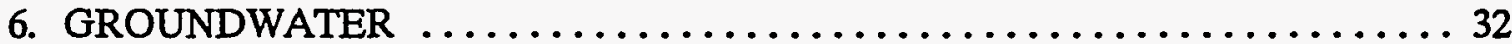

7. RISK ASSESSMENT $\ldots \ldots \ldots \ldots \ldots \ldots \ldots \ldots \ldots \ldots \ldots \ldots \ldots \ldots \ldots \ldots \ldots \ldots \ldots$

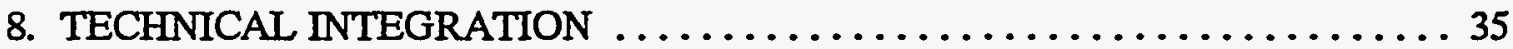

9. INFORMATION MANAGEMENT AND ANALYSIS $\ldots \ldots \ldots \ldots \ldots \ldots \ldots$

REFERENCES ................................ 38 


\section{FIGURES}

1 Waste area groupings in the vicinity of Oak Ridge National Laboratory ..... 2

2 Tributary assessment task sampling locations $\ldots \ldots \ldots \ldots \ldots \ldots \ldots \ldots$

3 Conceptual model for contaminated sediment transport in the

White Oak Creek Basin $\ldots \ldots \ldots \ldots \ldots \ldots \ldots \ldots \ldots \ldots \ldots \ldots \ldots \ldots$

$4 \quad$ Sediment erosion study sampling locations $\ldots \ldots \ldots \ldots \ldots \ldots \ldots \ldots \ldots$

$5 \quad$ Sampling sites for the sediment transport storm sampling subtask $\ldots \ldots \ldots \ldots 23$

\section{TABLES}

1 Phase I and Phase II components of project for FY $1995 \ldots \ldots \ldots \ldots \ldots \ldots$

$2 \quad$ Analyses for soil and sediment characterization task $\ldots \ldots \ldots \ldots \ldots \ldots \ldots$

3 Storm classification for sediment storm sampling subtask $\ldots \ldots \ldots \ldots \ldots 24$

$4 \quad$ Numbers of samples for radiological analysis for sediment transport

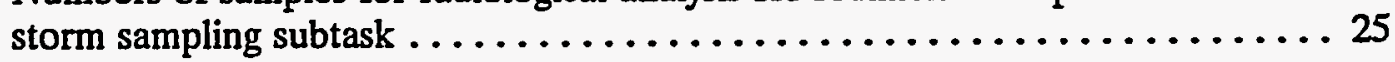

\section{DISCLAIMER}

This report was prepared as an account of work sponsored by an agency of the United States Government. Neither the United States Government nor any agency thereof, nor any of their employees, makes any warranty, express or implied, or assumes any legal liability or responsibility for the accuracy, completeness, or usefulness of any information, apparatus, product, or process disclosed, or represents that its use would not infringe privately owned rights. Reference herein to any specific commercial product, process, or service by trade name, trademark, manufacturer, or otherwise does not necessarily constitute or imply its endorsement, recommendation, or favoring by the United States Government or any agency thereof. The views and opinions of authors expressed herein do not necessarily state or reflect those of the United States Government or any agency thereof. 


\section{ABBREVIATIONS}

\begin{tabular}{ll} 
ARAR & applicable or relevant and appropriate requirement \\
ASTM & American Society for Testing and Materials \\
ATL & Aquatic Toxicology Laboratory (of ESD) \\
BERA & baseline ecological risk assessment \\
BMAP & Biological Monitoring and Abatement Program \\
CERCLA & Comprehensive Environmental Response, Compensation, and Liability Act \\
CLP & Contract Laboratory Program \\
DOE & U.S. Department of Energy \\
DQO & data quality objective \\
EPA & U.S. Environmental Protection Agency \\
ER & environmental restoration \\
ERMA & Environmental Restoration Monitoring and Assessment \\
ESD & Environmental Sciences Division (of ORNL) \\
ESP & East Seep \\
FFA & Federal Facility Agreement \\
FS & feasibility study \\
FY & fiscal year \\
GIS & Geographic Information System \\
HSPF & hydrologic simulation program-FORTRAN \\
ICP & inductively coupled plasma \\
IHP & Intermediate Holding Pond \\
OREIS & Oak Ridge Environmental Information System \\
ORNL & Oak Ridge National Laboratory \\
PCB & polychlorinated biphenyl \\
PORTS & Portsmouth Gaseous Diffusion Plant \\
QA QC & quality assurance/quality control \\
RCRA & Resource Conservation and Recovery Act \\
RI & remedial investigation \\
SI & site investigation \\
SOP & standard operating procedure \\
TDEC & Tennessee Department of Environment and Conservation \\
USRADS & Ultrasonic Ranging and Data System \\
WAG & waste area grouping \\
WET & White Oak Creek Embayment Tributary \\
WOC & White Oak Creek \\
WOCE & White Oak Creek Embayment \\
WOD & White Oak Dam \\
WOL & White Oak Lake \\
\hline
\end{tabular}


,

, 


\section{EXECUTIVE SUMMARY}

Field activities to support the remedial investigation (RI) of Waste Area Grouping (WAG) 2 at Oak Ridge National Laboratory (ORNL) include characterization of the nature and extent of contamination in WAG 2, specifically to support risk-based remediation decisions. WAG 2 is the major drainage system downgradient of other WAGs containing significant sources of contamination at ORNL. The RI of WAG 2 is developed in three phases: Phase I, initial scoping characterization to determine the need for early action; Phase II, interim activities during remediation of upgradient WAGs to evaluate potential changes in the contamination status of WAG 2 that would necessitate reevaluation of the need for early action; and Phase III, completion of the RI process following remediation of upslope WAGs. Specifically, Phase II activities are required to track key areas to determine if changes have occurred in WAG 2 that would require (1) interim remedial action to protect human health and the environment or (2) changes in remedial action plans and schedules for WAG 2 because of changing.contaminant release patterns in upslope WAGs or because of the effects of interim remedial or removal actions in other WAGs. This report defines activities to be conducted in FY 1995 for completion of the Phase I RI and initiation of limited Phase II field work.

At the June 1994 Data Quality Objective (DQO) Workshop, representatives of the U.S. Environmental Protection Agency (EPA) and the Tennessee Department of Environment and Conservation (TDEC) (i.e., the regulators) recommended separating the existing WAG 2 and Site Investigations (SI) Project from FY 1995 forward into two major stand-alone components: the WAG 2 RI and the ORNL Surface Water Program. The RI component is to complete Phase I RI work in FY 1995, initiate limited high-priority Phase II sampling activities in FY 1995, and conduct other specific tasking directed by the DQO process and regulator inputs. The SI component will become the core of a new organizational structure in the ORNL Environmental Restoration (ER) Program: the ORNL Surface Water Program, with tasking determined by ORNL ER Program management needs. In addition, the groundwater elements from the WAG 2 \& SI Project will also be completed in the short term with continuing elements consolidated into the new ORNL Area Groundwater Program. The watershed-level groundwater efforts that are now part of the WAG 2 \& SI Project will transition to the Area Groundwater Program. The ORNL Surface Water Program and Area Groundwater Program will provide the required support for the restoration of individual WAGs or operable units and integrate information and activities across the ORNL site. The WAG 2 RI will continue to focus on providing information specific to the remediation of WAG 2.

Federal Facility Agreement (FFA) managers, which include DOE-Oak Ridge Operations, EPA, and TDEC, have directed that FY 1995 RI work activities concentrate exclusively on meeting FFA requirements-specifically, (1) that a separate FY 1995 WAG 2 RI Work Plan be developed to replace the other project-level annual technical task scoping/planning documents previously specified in Appendix E of the FFA and (2) that the Work Plan be designated as the FFA FY 1995 deliverable for the WAG 2 RI. This report outlines the immediate activities needed to complete the WAG 2 Phase I RI in FY 1995, with emphasis

on analysis of existing data, data interpretation, and reporting of results. These activities 
include (1) completion of Phase I RI work in seeps and tributaries, (2) completion of Phase I RI activities in the area of sediment characterization, (3) completion of Phase I activities in sediment transport modeling, (4) completion of Phase I field work in terrestrial biota sampling and aquatic biota/benthic invertebrate sampling and ecological assessment, (5) completion of RI-related groundwater contamination investigation activities in WAG 2, and (6) initiation of Phase II field work in sediment erosion and composition determination. 


\section{INTRODUCTION}

\subsection{PURPOSE AND PROJECT SCOPE}

The purpose of this project is to provide key information needed by decision makers to expedite the process of environmental restoration and to provide the data base required by the Remedial Investigation/Feasibility Study (RI/FS) for Waste Area Grouping (WAG) 2 at Oak Ridge National Laboratory (ORNL). WAG 2 is the major drainage system downgradient of other WAGs that contain significant sources of contamination at ORNL (Fig. 1). Field activities to support the remedial investigation for the $\mathrm{RI}$ portion include characterization of the nature and extent of contamination in WAG 2 [consisting of White Oak Creek (WOC) and associated tributaries and floodplain, White Oak Lake (WOL), and White Oak Creek Embayment (WOCE)], specifically to support risk-based remediation decisions. The project consists of three phases: Phase I, initial scoping characterization to determine the need for early action; Phase II, interim activities during remediation of upslope WAGs to evaluate potential changes in the contamination status of WAG 2 that would necessitate reevaluation of the need for early action; and Phase III, completion of the RI process following remediation of upslope WAGs. Overall RI objectives, consistent with ORNL Environmental Restoration (ER) Program strategic objectives to reduce risks and comply with environmental regulations, are discussed in the WAG 2 Remedial Investigation Plan (ORNL 1990).

More specifically, Phase I RI activities are required to (1) provide information to evaluate the need for early action through potential human health and environmental risk effects, (2) provide data for preliminary planning for scoping final WAG 2 remedial action alternatives, and (3) provide information to predict possible impacts of remediation of upgradient WAGs. Phase II activities are designed to track the effects on resident biota from WAG 2 contaminants and to determine the need for any interim actions in WAG 2. Phase III activities will concentrate on collecting information to support the selection, design, and implementation of final remedial action in WAG 2.

A substantial amount of information characterizing contamination in WAG 2 has been collected since FY 1992, and a report summarizing Phase I RI results to date was published (DOE 1993a). Work planned for FY 1995 includes activities necessary to complete Phase I of the RI and to initiate Phase II field sampling and analysis activities. The WAG 2 RI Phase I final report will be delivered in FY 1996; this report will include analysis and discussion of completed Phase I work and will propose a regimen of continuing Phase II activities. Phase $I I$ activities are those needed to track key areas to determine if changes have occurred in WAG 2 that would require (1) interim remedial action to protect human health and the environment or (2) changes in remedial action plans and schedules for WAG 2 because of changing contaminant release patterns in upslope WAGs or because of changes brought about by the effects of interim remedial or removal actions in other WAGs. Phase II activities are expected to be conducted at a significantly lower level of activity than those conducted during Phase I. The key areas for Phase II RI work include analyzing sediment samples and biota to determine impacts attributable to WAG 2 only and impacts on other species in the direct food chain of WAG 2-resident biota. This determination requires monitoring biota that can indicate the need for interim action or signal changes in 
2

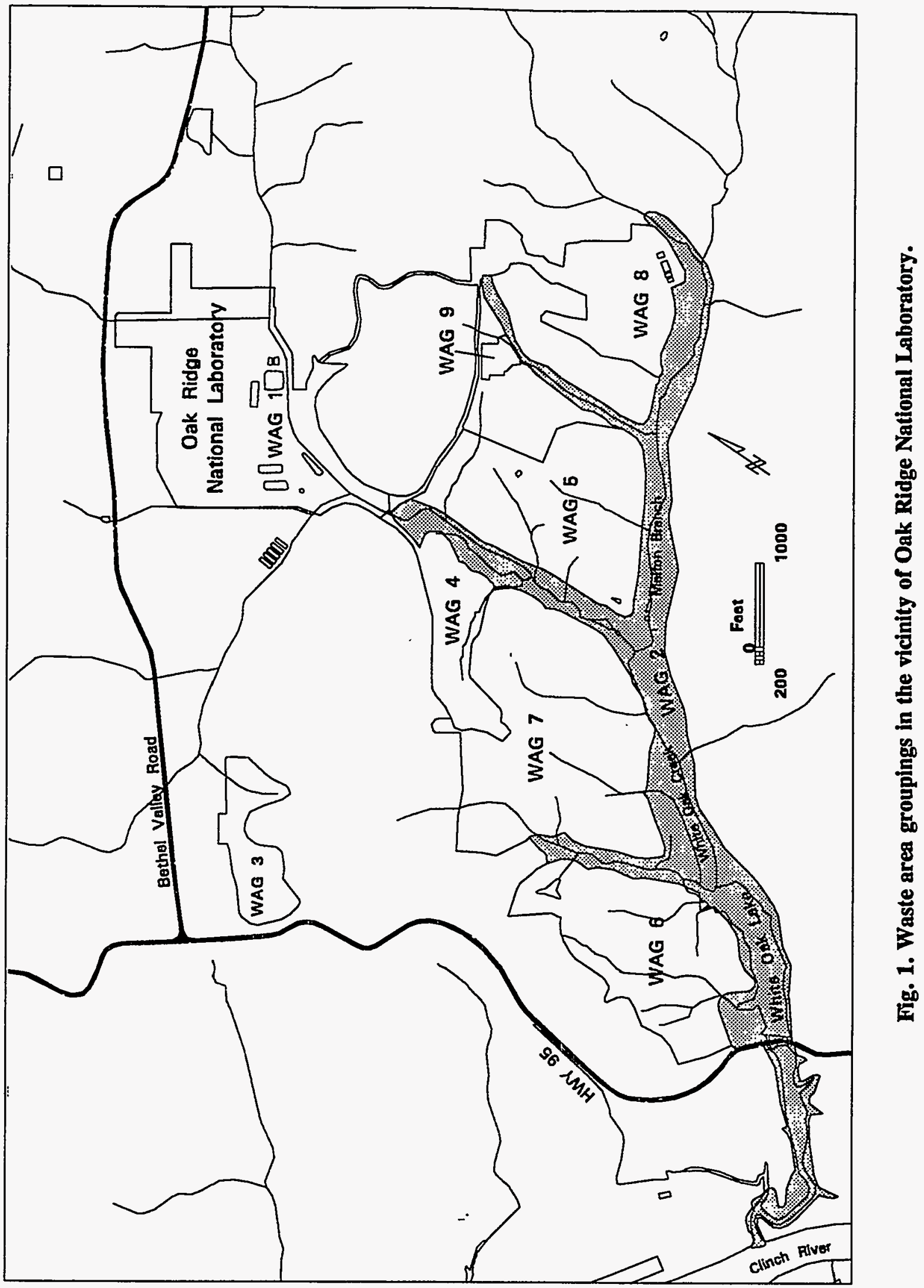


understanding of remedial needs for WAG 2. Specific tasking is based on direction received from the regulators at the Data Quality Objective (DQO) Workshop completed in June 1994. Definition of Phase II biota monitoring activities will be based on recommendations developed from the ecological risk assessment that will be initiated in FY 1995.

\subsection{BACKGROUND}

ORNL was established in 1943, and over 50 years of operations have produced a legacy of contaminated inactive facilities, research areas, and waste disposal areas that are potential candidates for remedial action. Because of the large number of sites and the complex hydrology and geology at ORNL, the strategy developed in response to regulatory requirements has been oriented toward WAGs rather than individual sites. WAGs are generally defined by local geographic watersheds or drainage basins that contain contiguous and similar remedial action sites. In some cases, there has been hydrologic interaction among the sites within a WAG, making individual sites hydrologically inseparable.

The ORNL ER Program was established to coordinate the U.S. Department of Energy's (DOE's) response obligations to the Comprehensive Environmental Response, Compensation, and Liability Act (CERCLA), the Resource Conservation and Recovery Act (RCRA), and other relevant regulations. The program manages remedial efforts to achieve comprehensive remediation of releases and threatened releases of hazardous substances, hazardous wastes, and pollutants or contaminants at or from ORNL. The ORNL ER Program follows the structured CERCLA path of site characterization, site maintenance and surveillance, interim corrective action, alternatives assessment, technology development, engineering design, and eventual site closure or remediation.

The WAG 2 Remedial Investigation and Site Investigations (SI) Project, in place through FY 1994, fulfills requirements of the CERCLA RI/FS process for WAG 2 and, with the associated SI studies, represents a series of directed investigations addressing the movement of contaminants for the ORNL WAGs. RCRA requirements are also important considerations in WAG 2, and coordination of CERCLA and RCRA is addressed more fully in the Phase I RI report (DOE 1993a) and in the RI Work Plan (ORNL 1990).

WAG 2 consists of one operable unit, which includes WOC surface water and streams/tributaries located downgradient of the ORNL main plant area, WOL, WOCE on the Clinch River, and the associated sediments and floodplain soils and the subsurface environment from the approximate 100-year flood elevation to the Clinch River. The WOC system is the surface drainage for the major ORNL WAGs, and it has been exposed to a diverse array of contaminants from operations and waste disposal activities in the WOC watershed. These can include tritium, fission and nuclear activation products, transuranics, polychlorinated biphenyls (PCBs), volatile organic compounds, and various metals (e.g., $\mathrm{Cu}$, $\mathrm{Hg}, \mathrm{Mo}, \mathrm{Ni}, \mathrm{Pb}$, and $\mathrm{Zn}$ ). WAG 2 is important as a conduit to the Clinch River for upgradient areas and as one of two major integrators of the contaminant releases from ORNL WAGs in the WOC watershed. Water, sediment, soils, and biota in WAG 2 have been contaminated as a result of past disposal practices at ORNL, and contaminants continue to migrate from upgradient WAGs.

The strategy developed for the WAG 2 efforts uses information collected in WAG 2 to support the remediation of individual upgradient sites, while providing an integrated measure 
that will serve as a performance indicator for remedial efforts of contaminant releases from all sites (see Fig 1). Most ORNL facilities are in one watershed, the WOC watershed, and the shallow subsurface flowpath system is the receptor for contaminants released from individual waste sites and a conduit for contaminant transport to streams that run off-site. Data collected at key locations in the watershed are linked with information from environmental investigations to (1) identify contaminant sources and quantify contaminant fluxes, (2) identify the contaminants and pathways of concern for human health and ecological risk, (3) improve conceptual models of contaminant movement, (4) identify remedial alternatives and collect information to support the evaluation and implementation of those alternatives, (5) prioritize sites for remediation, and (6) document reduced contaminant fluxes following remediation (ORNL 1990). Of these, items 1 through 5 have been addressed. Item 6 will be addressed after completion of remedial or removal actions in other WAGs. Several actions have been initiated (WAG 1 and WAG 5 Seep Area C and D cleanups). The Engineering Evaluation/Cost Assessment for First Creek seep is in the public review stage, and monitoring to document performance of this action will be required during FY 1995.

\subsection{DATA QUALITY OBJECTIVES WORKSHOP}

At the June 1994 DQO Workshop, representatives of the U.S. Environmental Protection Agency (EPA) and the Tennessee Department of Environment and Conservation (TDEC) recommended separating the existing WAG 2 \& SI Project during FY 1995 into two major stand-alone components: the WAG 2 RI and the ORNL Surface Water Program. The RI component is to complete Phase I RI work in FY 1995, initiate high-priority short-term Phase II sampling activities in FY 1995, and conduct other specific tasking directed by the DQO process and regulator inputs. The SI component will become the core of a new organizational structure in the ORNL ER Program-the ORNL Surface Water Program-with tasking determined by ORNL ER Program management needs. In addition, the groundwater elements from the WAG 2 \& SI Project will be completed in the short term with continuing elements consolidated into the new ORNL Area Groundwater Program. The ORNL Groundwater Operable Unit Program is currently the second integrator WAG unit for the ORNL site. The watershed-level groundwater efforts that are now part of the WAG 2 \& SI Project will transition to the Area Groundwater Program. The ORNL Surface Water Program and Area Groundwater Program will provide the required support for RI/FS of individual WAGs or operable units and integrate information and activities across the ORNL site. The WAG 2 RI will continue to focus on providing information specific to the remediation of WAG 2.

Potential problems related to surface water, sediment, and shallow groundwater were addressed at the DQO Workshop and evaluated to identify issues that could cause immediate risk to human health at the Clinch River and ecological risk within WAG 2. The following issues were identified:

\section{Human Health}

- Preliminary modeling indicates that potential risk greater than $1 \times 10^{-4}$ at the Clinch River may exist if a 100-year flood event occurs. This risk is primarily due to transport of contaminated sediment and dissolved solids over the White Oak Dam (WOD) into the Clinch River system in cases of flood. 
- WOL and WOD currently act as barriers to decrease sediment transport and contaminant transport to the Clinch River. This is not a satisfactory final remediation. The problem is to determine how long this kind of de facto barrier will effectively prevent transport of sediments. Actions prior to final remediation may be warranted if the probability of contaminated sediment transport increases before final remedial decisions are made for WAG 2 . Understanding the amount of sediment that may be held in WOL will allow effective timing of the final remedial actions both in WAG 2 and in source WAGs and will prevent contaminated sediment from flowing into the Clinch River.

\section{Ecological}

- Contaminants in WAG 2 may cause toxic effects in aquatic and terrestrial biota.

- Contamination in biota in WAG 2 may be transferred through the food chain to other biota.

- WAG 2 sediments may contribute to toxic effects in transient biota.

The phased approach to the WAG 2 RI was further clarified. Phase I will address information required for the identification of the nature and extent of the contamination issues in WAG 2 and will also provide information to determine if any immediate remedial actions are warranted. Phase II will focus on determining whether actions upgradient of WAG 2 are changing current risk conditions resulting from effects on WAG 2 contaminant sources.

Phase I decisions will relate to a current evaluation of the nature and extent of contamination to determine if immediate actions are needed with respect to WAG 2 contaminant sources (e.g., WOL). Presently, DOE does not believe that there are any issues that will warrant immediate action. Phase II decisions focus on assessing change to the current system to ensure that conditions do not worsen to the extent that immediate actions are warranted.

\subsubsection{Phase I Decisions}

Unless immediate action is warranted because of significant risk off-site, it was agreed that remedial action decisions in WAG 2 would be delayed until the source WAGs begin to complete remedial actions. To date, no immediate need for action has been identified based on off-site risk originating from WAG 2 sources. However, immediate actions in other WAGs call for efforts to reduce risk at WOD by reducing contamination into WOC from other WAGs.

The following decisions are related to the issues discussed above.

\section{Human Health}

- Will a 100-year flood cause human health risk at the Clinch River to exceed $1 \times 10^{-4}$ ? If this is the case, preventative actions must be evaluated at an earlier time than is currently planned. 
- At what point will sediment deposition in WOL increase to such a degree that human health risks downstream at the Clinch River exceed $1 \times 10^{-6}$ as a result of dissolved and sediment-bound contaminants?

\section{Ecological}

- Are aquatic communities in WOC sufficiently impacted by contaminants to evaluate the need for immediate action?

- Does contaminant accumulation by aquatic biota in WOC result in sufficient ecological risk to terrestrial biota to evaluate the need for immediate action?

- Does contaminant accumulation by terrestrial biota in the WOC floodplain result in sufficient ecological risk to evaluate the need for immediate action?

- Is immediate action warranted if ecological risk is high but the particular species do not roam widely and remain on the reservation?

\subsubsection{Phase II Decisions}

Completion of upstream source remediation will be several years away. The final remedial investigation of WAG 2 will not occur until the upstream source operable units have been remediated. Continuing contaminant influx to WAG 2 in this interim period will require a routine evaluation of WAG 2 contamination problems and associated risks to ensure that no need for accelerated action arises and to maintain an updated baseline data base.

The following task areas require attention at this time:

1. complete needed Phase I activities-determine the extent of contamination in biota and whether severe impacts to the ecological system have occurred in WAG 2, such that consideration of immediate action is warranted, and

2. initiate planned Phase II work-determine whether actions upgradient in other WAGs are impacting current risk estimates in WAG 2.

Planned Phase II work includes (1) collecting data on sediment erosion and sediment composition in WOL to ensure detection of significant changes in potential off-site sediment flux, (2) tracking erosion of major contaminated sediment source areas in WAG 2 [i.e., the Intermediate Holding Pond (IHP) site], and (3) evaluating and assessing changes in terrestrial ecological risk (to follow completion of Phase I ecological risk assessment).

Federal Facility Agreement (FFA) managers, that include EPA and TDEC, directed that work activities concentrate on meeting CERCLA and FFA requirements-specifically, that (1) a separate FY 1995 WAG 2 RI Work Plan be developed to replace the other projectlevel, annual technical task scoping/planning documents previously specified in Appendix $\mathrm{E}$ of the FFA and (2) the Work Plan be designated as the FY 1995 FFA deliverable for the WAG 2 RI. The document is to outline the immediate activities needed to complete Phase I of the WAG 2 RI in FY 1995, with emphasis on analysis of existing data, data interpretation, and reporting of results. Specifically, this task includes (1) completion of Phase I RI work in seeps and tributaries, (2) completion of Phase I RI activities in the area of sediment 
characterization, (3) completion of Phase I activities in sediment transport modeling, (4) completion of Phase I field work in terrestrial biota sampling and aquatic biota/benthic invertebrate sampling and ecological assessment, (5) completion of RI-related groundwater contamination investigation activities in WAG 2, and (6) initiation of Phase II field work in sediment erosion sampling and analysis for determination of sediment composition. 


\section{REMEDIAL INVESTIGATION ACTIVITIES FOR WAG 2 IN FY 1995}

\subsection{CONCEPTUAL MODEL FOR WAG 2}

The conceptual model for contaminant movement through WAG 2 is complex and not yet fully defined. The majority of soluble contaminants presently being leached from the buried wastes in the ORNL source WAGs (principally ${ }^{3} \mathrm{H}$ and ${ }^{90} \mathrm{Sr}$ ) are transported out of the source WAGs through surface water or groundwater in the shallow subsurface; only a small $(<5 \%)$ fraction appears to enter the deep subsurface groundwater. WAG 2 serves as the principal conduit for transport of contaminants from the ORNL source WAGs off-site via the surface water pathway.

In the present understanding of the mechanism for contaminant transport into the WAG 2 surface water system, wastes buried in source WAGs are periodically "rinsed" with infiltrated rainwater or inundated with shallow groundwater during periods of heavy rainfall in which the elevation of the water table rises or perched water tables are temporarily created. Contaminants are then subject to transport to receiving streams via the subsurface stormflow zone and lateral flow in the shallow water table interval. In this way, contaminants leached from buried wastes are transported through the shallow subsurface pathways and drain into the surface water system both through visible seeps and through nonpoint discharges. During seasonal increases in the water table elevation in the winter and early spring and during high rainfall events, contaminant fluxes increase because of increased flushing of contaminants through the shallow subsurface.

Principal contaminants of concern contained within WAG 2 itself are the more particle-reactive species $\left({ }^{137} \mathrm{Cs},{ }^{60} \mathrm{Co}\right.$, and $\left.\mathrm{PCBs}\right)$. These contaminants have accumulated in WAG 2 in sediments both from upstream discharges during the past 50 years of ORNL operations and from leaching of buried wastes in the source WAGs. Contaminated sediments may be mobilized and transported during high-flow conditions; particle-reactive contaminants from upstream sources may also be deposited in WAG 2 during certain rainfall events. The hydrologic conditions and locations within WAG 2 which result in sources or sinks for particle-reactive contaminants are not well defined at present. Work proposed during FY 1995 will be directed principally toward resolving uncertainties in the distribution and transport behavior of these particle-reactive contaminants in order to evaluate human health risks associated with these materials, as well as collecting data to evaluate the ecological risks associated with both soluble and particle-reactive contaminants in WAG 2.

\section{CURRENT UNDERSTANDING OF WAG 2}

Current understanding of WAG 2 can be summarized as follows.

- WAG 2 represents a major source of potential human health risk and ecological risk at ORNL. These risks are attributable to contamination from buried sources within other WAGs hydrologically upgradient of WAG 2 and from contaminated sediments located primarily in the WOL floodplain and in the IHP. The primary indicators of direct evidence in this area are impacts of WAG 2-specific contaminants on biota in WAG 2. 
- The potential for contaminant releases attributable to WAG 2 and for subsequent exposure to humans and biota exists and must be monitored and assessed.

- Based on past evidence and the level of current knowledge, there is no demonstrated need at this time for early action in WAG 2 . The strategy of continued monitoring and analysis/assessment should and will be maintained and reviewed periodically to reaffirm the validity of this approach.

- Potential future actions may include early action in the event of elevated sediment transport into WAG 2 and concomitant sudden releases of contaminants from a significant rainfall or flooding event.

\subsection{ACTION PLAN}

The action plan to be pursued in FY $1995 \mathrm{RI}$ activities in WAG 2 includes two major elements: (1) completion of Phase I RI activities and (2) initiation of limited Phase II RI monitoring and analysis work in the field.

Phase I of the project includes (1) determining the need for early action in WAG 2 based on potential human health risk and ecological risk to biota in WAG 2, (2) obtaining pertinent information to define the scope of final remedial action in WAG 2, and (3) providing information to predict possible impacts on WAG 2 of remedial actions in upgradient WAGs.

Phase II activities include obtaining the data necessary to reevaluate the need for any interim actions before the final remedial action.

Phase III activities include collecting information to support selection of remedial technology and implementation of the final remedial action in WAG 2.

Progress in achieving Phase I objectives has been reported in the WAG 2 Phase I RI report (DOE 1993a), which includes discussion of preliminary results. Recent progress in FY 1994 includes achieving the initial phase objectives specified in the WAG 2 RI Work Plan (ORNL 1990).

Phase I actions to complete and Phase II actions to initiate in FY 1995 include (1) completion of Phase I RI work in seeps and tributaries, (2) completion of Phase I RI activities in the area of sediment characterization, (3) completion of Phase I activities in sediment transport modeling, (4) completion of Phase I field work in terrestrial biota sampling and aquatic biota/benthic invertebrate sampling and ecological assessment as part of interim activities during remediation of upgradient WAGs to reevaluate the need for early action in WAG 2, (5) completion of RI-related groundwater contamination investigation activities in WAG 2, and (6) initiation of limited Phase II field work in tracking sediment erosion and determining composition. Completion of the seep and tributary assessment work previously done as part of WAG 2 \& SI activities will be conducted in the ORNL Surface Water Program.

The approach in conducting limited field activities during Phase II in WAG 2 centers on two areas: (1) characterization and baselining of the sediment medium in WAG 2 in order 
to gauge future erosion of soil and sediment and (2) determination of the effects and impacts on biota that can act as indicators of contaminant movement in WAG 2 and the baselining these effects to signal future changes that may be precursors to interim actions or early action. Recommendations for Phase II biota monitoring will be developed from the ecological risk assessment.

The initial efforts to be undertaken in FY 1995 as part of Phase II RI activities include the specific tasks identified and discussed in Sects. 4 and 5 of this report.

All field work will be conducted in accordance with the approved WAG 2 Quality Assurance Plan (ORNL 1992b) and the WAG 2 Health and Safety Plan (ORNL 1993b). References to all field sampling procedures and analytical laboratory methods to be used in RI-related activities are contained in the WAG 2 Field Sampling and Analysis Plan (DOE 1992a) and the WAG 2 Field Sampling and Analysis Plan-Responses to Comments (DOE 1992b).

\section{COMPONENTS OF PROJECT FOR FY 1995}

Table 1 shows Phase I and Phase II components of the RI that will be performed in FY 1995 to complete Phase I and initiate work in Phase II. 
Table 1. Phase I and Phase II components of project for FY 1995

\begin{tabular}{|c|c|c|}
\hline Task/Subtask & Phase I & Phase II \\
\hline \multicolumn{3}{|l|}{ Sediment and Soil Characterization Task } \\
\hline Soil characterization assessment & $\mathbf{X}$ & \\
\hline Bathymetry of White Oak Lake & $\mathrm{X}$ & \\
\hline Erosion rates & $\mathrm{X}$ & \\
\hline IHP site radionuclide inventory & $X$ & \\
\hline White Oak Lake coring & $\mathrm{X}$ & \\
\hline \multicolumn{3}{|l|}{ Sediment Transport Modeling Task } \\
\hline Sediment transport simulation & $\mathrm{X}$ & \\
\hline Sediment transport data package & $\mathrm{X}$ & \\
\hline Sediment transport storm sampling & $\mathrm{X}$ & $X$ \\
\hline Biota Task & & $\bar{a}$ \\
\hline Mink and kingfisher monitoring & $\mathbf{X}$ & \\
\hline Soil toxicity testing & $\mathrm{X}$ & \\
\hline Sediment toxicity testing & $\mathbf{X}$ & \\
\hline Earthworm sampling and analysis & $\mathrm{X}$ & \\
\hline Shrew sampling and analysis & $\mathbf{X}$ & \\
\hline \multicolumn{3}{|l|}{ Ecological Risk Assessment Task } \\
\hline Initiation of ecological risk assessment process & $\mathbf{X}$ & \\
\hline \multicolumn{3}{|l|}{ Groundwater } \\
\hline Data summary report & $\mathbf{X}$ & \\
\hline \multicolumn{3}{|l|}{ Risk Assessment } \\
\hline Phase I human health risk assessment report & $\mathbf{X}$ & \\
\hline \multicolumn{3}{|l|}{ Technical Integration } \\
\hline Direct interaction with other WAGs and data exchange & $\mathbf{X}$ & $\mathbf{X}$ \\
\hline \multicolumn{3}{|l|}{ Information Management and Analysis } \\
\hline Continue project support & $\mathrm{X}$ & $\mathrm{X}$ \\
\hline
\end{tabular}

${ }^{a}$ To be determined following completion of the ecological risk assessment, which will be a baseline ecological risk assessment for an early action. 


\section{SURFACE WATER}

\subsection{WATERSHED HYDROLOGY}

Surface water is the major conduit for and receptor of contaminant fluxes from waste sources in the WOC watershed and the primary pathway for contaminant transport and migration to the off-site environment. Quality hydrologic data are needed to quantify and evaluate contaminant fluxes (total load) leaving the ORNL site. Accurate flux determinations are necessary to evaluate human health and ecological risk and to monitor the effectiveness of remedial actions. In addition, high-quality stream discharge data and precipitation data are imperative to develop predictive models to evaluate scenarios based on remediation alternatives, future land use, and extreme hydrologic events.

This task has collected meteorological data and has maintained and monitored the network of surface water monitoring stations in the WOC watershed in previous fiscal years. During FY 1995, no additional data for surface water will be collected under the WAG 2 RI scope of work. However, critical flood-discharge data and meteorological data will be provided to support the sediment transport modeling task by generating information on frequency (return periods) of extreme discharge events for WOC from available extreme-event rainfall data. This information will be applied to the calibrated hydrologic simulation program-FORTRAN (HSPF) model to support simulations of contaminated sediment transport. In this way, the watershed hydrology task supports evaluation of the potential for off-site human health risk due to sediment transport during extreme events.

\subsection{SEEP}

The primary objective of the WAG 2 seep task is to identify seeps and tributaries that are responsible for contaminant fluxes in WAG 2 . The major pathways for water movement and associated contaminants in the subsurface are through the shallow water table and the stormflow zone (ORNL 1992a). Water that infiltrates the soil surface moves through these shallow pathways intercepting and leaching contaminants from primary sources (trenches) and/or secondary sources (downgradient soil matrix) and then discharges to the surface water system. The groundwater discharge areas (i.e., seeps and springs) mark the preferred groundwater and contaminant flow pathways. Tributaries serve as spatial integrators of contaminant releases from larger areas adjacent to WAG 2. In addition, sampling along stream reaches (transects) is useful for identifying areas of significant contaminated groundwater discharge directly to the stream channel. Water quality sampling of seeps, springs, tributaries, and stream reaches has been conducted for the last 3 years to identify and quantify the contaminant releases to WAG 2. Initially, two extensive screening sampling rounds were conducted during baseflow conditions in FY 1992. Results from these sampling rounds identified key seeps and areas that contribute significantly to the total contaminant flux in WAG 2 (DOE 1993a). Removal actions have been initiated on two of these areas as a result (ORNL 1993a).

During FY 1993 two more extensive baseflow sampling rounds were completed. A round of samples was also collected following a large rain event when subsurface stormflow was active. Bimonthly sampling in and around approximately ten key source areas was initiated 
in May 1993 and continued through FY 1994. Results from all these sampling rounds will provide distributions of contaminant fluxes and source areas throughout the WOC watershed. The results will also enhance our understanding of the effects of different hydrologic conditions on contaminant transport. In FY 1995, the extensive FY 1993 and 1994 data will be summarized, analyzed, and interpreted in a report. Source areas will be identified and then prioritized based on risk to provide guidance for potential corrective actions.

\subsection{TRIBUTARY ASSESSMENT}

Tributary water quality samples are important in identifying significant contributors to offsite contaminant flux in prioritizing sites for remediation. Determination of the relationship between stream discharge rate $(Q)$ and contaminant concentration $(C)$ (and hence flux) supports the future evaluation of the effectiveness of remedial measures (performance monitoring). Comparing $C-Q$ relationships before and after remediation tends to remove the meteorological influence because the relationships incorporate variations caused by changes in meteorological conditions and individual storms. Therefore, this method is intended to provide a relatively quick indication of improvement resulting from remediation, as opposed to observing groundwater that may not show significant improvement for decades.

The tributary monitoring and evaluation program was initiated in FY 1993 as part of the seeps and tributaries task to identify potential contaminant sources discharging directly to tributaries and to complement the prioritization of sites (from a risk/dose perspective) for remediation. Preliminary sampling conducted during the initial phase of the task supplemented the data collection activities of the seep task. This effort resulted in the prioritization of 17 tributary locations (Fig. 2), according to contribution to off-site contaminant flux and risk, and the identification of sites for subsequent intensive sampling and characterization. The initial grab sampling event was conducted at the 17 tributary sites to measure radionuclides and metals of concern for contribution to risk. A second grab sampling event, intended to be a follow-up to the initial phase for prioritization of sites, was scheduled to be conducted in FY 1994. However, evaluation of data from the first round of samples, coupled with multiple baseflow and post-storm sampling events conducted by the Seep task, resulted in the determination that a second grab sampling event was unnecessary and would provide no additional information on prioritization of sites.

The second phase of the Tributary Assessment task, conducted in the latter part of FY 1993 and FY 1994, consisted of intensive sampling of four tributary sites (East Seep, Monitoring Station 1, T2A, and Homogeneous Reactor Test) during storms, coupled with baseflow grab sampling. Multiple storm events, representing different periods (seasons) of the hydrologic cycle, have been intensively sampled at each site. The primary objective of this effort is to determine baseline $C-Q$ (and hence contaminant flux) relationships for radionuclides of concern (from a risk/dose perspective) for tributaries contributing significantly to the flux at WOD and, therefore, the total risk to human health and the environment. In addition, secondary objectives are to calculate annual fluxes of contaminants from source WAGs contributing to off-site release, to support the decision making process for prioritization of sites for remediation, and to support the future evaluation and verification of the effectiveness of remedial actions.

During FY 1995, data collected from tributary sampling sites will be compiled and analyzed to complete the supplemental identification of source areas and prioritization based 


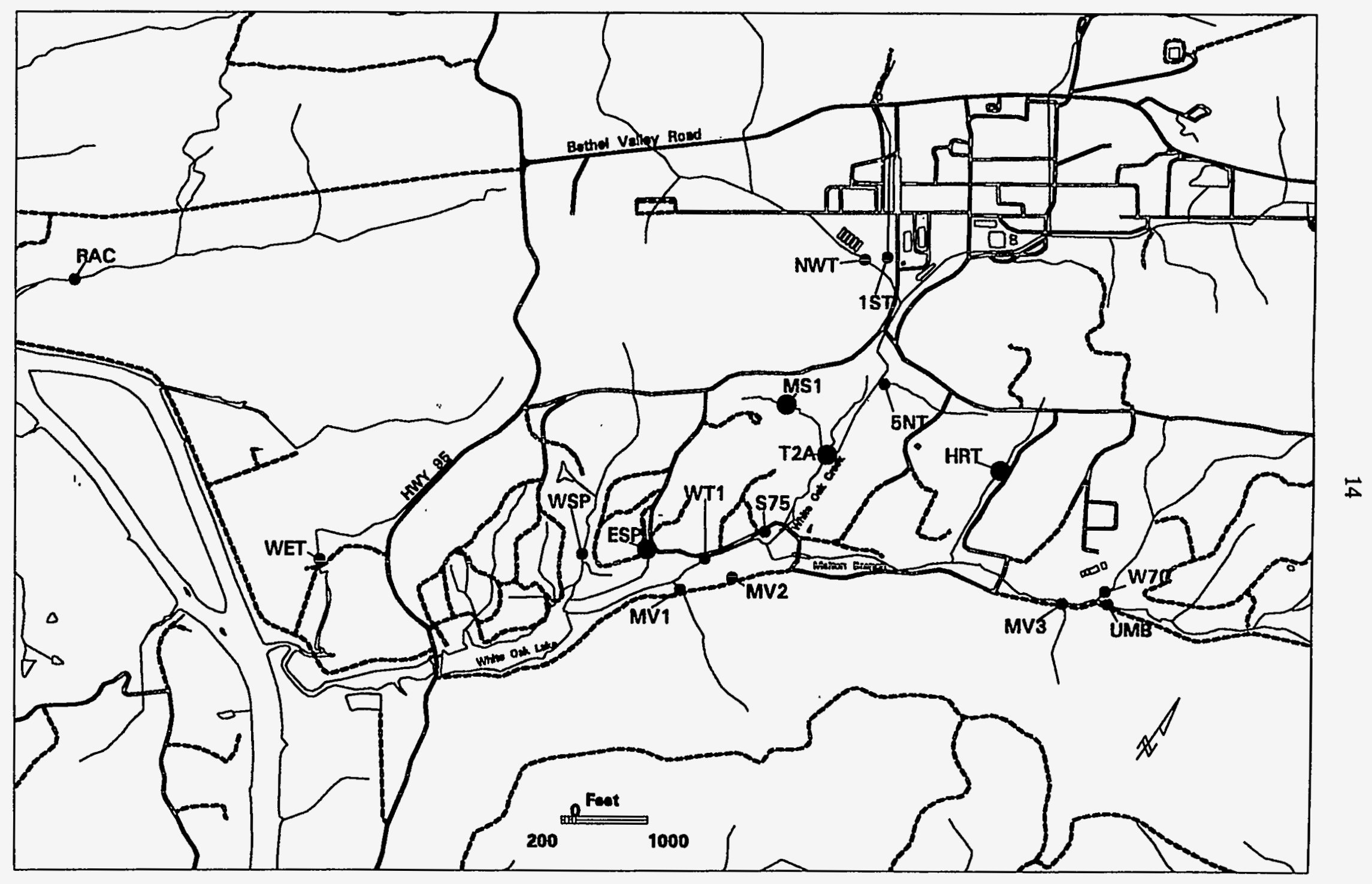

Fig. 2. Tributary assessment task sampling locations. 
on risk (to support the seep task), to complete the baseline determination of $C-Q$ relationships for radionuclides of concern (from a risk/dose perspective), and to interpret the data according to applicable or relevant and appropriate requirement (ARAR) guidance and impacts or modifications to the tributary conceptual model. These data will be used to calculate annual fluxes of contaminants from the tributaries (source WAGs) sampled to determine contribution to off-site releases and will be available to support the decision making process for prioritization of sites for remediation, as well as future evaluation and verification of the effectiveness of remedial actions. A report will be generated to summarize and assess the tributary assessment data collected in FY 1993 and FY 1994 to complete Phase I RI activities for this task. 


\section{SEDIMENT AND SOILS}

\subsection{SEDIMENT AND SOIL CHARACTERIZATION TASK}

A contaminant screening for WAG 2 found ${ }^{137} \mathrm{Cs}$ in aquatic and floodplain sediment to be one of the primary contributors to on-site human health risk. Fig. 3 shows the conceptual model of the storage and transport pathways for contaminated sediment in WAG 2. Little is known about the quantities of contaminants other than ${ }^{137} \mathrm{Cs}$. The purposes of this task are to (1) determine contaminant inventories, (2) identify source areas, and (3) determine the potential for off-site movement of contaminants. Work to characterize contaminant inventories is intended to complete the Phase I RI characterization goal. Efforts to identify mobile contaminants and erosion rates support the off-site sediment transport simulations discussed in the next task description. Results from this task will be reported in a programlevel data package and included in the sediment transport report, which is also identified in the next task description.

\subsubsection{Soil Characterization Assessment Subtask}

Data collected over the past 2 years will be analyzed and assessed. Based on Phase I soil sampling, vertical and spatial distributions of contaminants (i.e., radionuclides, metals, and organics) in WOC floodplain in WAG 2 will be analyzed and graphed. Results will comprise a project-level data package.

\subsubsection{Intermediate Holding Pond Site Radionuclide Inventory Subtask}

A new set of 40 cores will be collected in the IHP parallel to WOC in the upper $0.5 \mathrm{~m}$ (Table 2). Each soil core will be sectioned every $10 \mathrm{~cm}$, and the ${ }^{137} \mathrm{Cs}$ and ${ }^{60} \mathrm{Co}$ distributions will be determined. Relatively close sectioning of cores is required because of expected high vertical variability; small sections are needed to adequately describe vertical distributions. These data, in conjunction with estimates of erosion rate, will be used to estimate the contaminant flux from the IHP during storms of varying hydrologic recurrence frequencies. Exposures will be calculated from contaminant concentrations and compared with radionuclide levels determined from the Ultrasonic Ranging and Data System (USRADS ${ }^{\star}$ ) gamma walk-over data (collected in 1993) and beta/gamma hand-held instrument data.

Siting of core sample locations is planned for early FY 1995. Coring sites will be located by first identifying six transects, approximately equally spaced within the IHP. Within those transects, in each case 3 specific coring locations will be selected within $3 \mathrm{~m}$ of the existing WOC stream bank.

\subsubsection{Bathymetry of White Oak Lake Subtask}

Bathymetric mapping (i.e., water depth measurement) of WOL and WOCE will continue in FY 1995 to provide information on sediment inventories, filling rates, sinks and sources of contaminated sediment, and the potential for off-site transport of contaminants during large storms. Results of mapping will also be used to direct core sampling of sediment and to identify locations for obtaining samples for shear stress measurements. This task will be linked closely with the sediment transport modeling task. 
ORNL-DWG 93N-9202R2

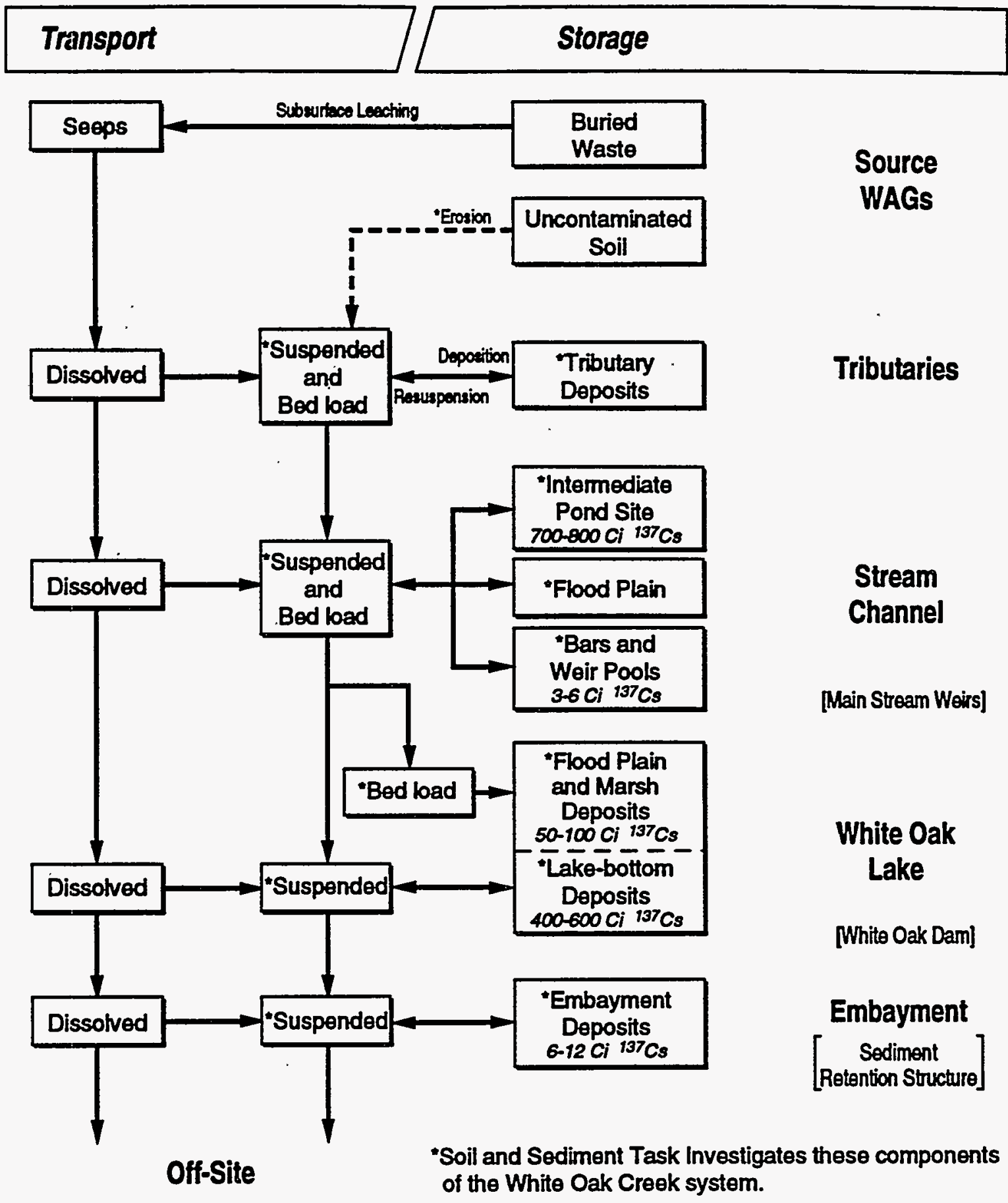

Fig. 3. Conceptual model for contaminated sediment transport in the White Oak Creek Basin. 


\subsubsection{White Oak Lake Coring Subtask}

WOL sediment samples were collected in previous studies; however, the samples were analyzed for only a few radionuclides. During FY 199510 cores will be collected in WOL, divided into the upper ( 0 to $15 \mathrm{~cm}$ ) and lower $(15 \mathrm{~cm}$ to bottom) subsamples, and the subsamples will be analyzed for radionuclides, metals, and organics (see Table 2).

Table 2. Analyses for soil and sediment characterization task

\begin{tabular}{|c|c|c|c|c|c|c|}
\hline Site & $\begin{array}{l}\text { No. of } \\
\text { cores }\end{array}$ & $\begin{array}{c}\text { No. of } \\
\text { samples }\end{array}$ & $\operatorname{Rads}^{b}$ & $\begin{array}{l}\text { ICP metals } \\
\text { and } \mathrm{Hg}\end{array}$ & $\begin{array}{c}\text { Semi- } \\
\text { volatiles }\end{array}$ & $\begin{array}{c}\text { PCBs/ } \\
\text { pesticides }\end{array}$ \\
\hline IHP cores ${ }^{c}$ & 40 & 126 & 126 & & & \\
\hline WOL cores & 10 & 24 & 24 & 24 & 24 & 24 \\
\hline
\end{tabular}

The following is the analyte list for sediment samples:

- organics: CLP Target Compound List for semivolatiles, pesticides, and PCBs

- metals: ICP: $\mathrm{Al}, \mathrm{Ba}, \mathrm{Be}, \mathrm{B}, \mathrm{Co}, \mathrm{Cu}, \mathrm{Fe}, \mathrm{K}, \mathrm{Mg}, \mathrm{Mn}, \mathrm{Mo}, \mathrm{Na}, \mathrm{Ni}$, Silica, Sn, Sr, V, $\mathrm{Zn}$

GFFA: As, Cd, $\mathrm{Cr}, \mathrm{Sb}, \mathrm{Ag}, \mathrm{Se}, \mathrm{Pb}, \mathrm{Tl}$

CVAA: $\mathrm{Hg}$

Specific analytical methods are discussed in Sect. 4.1.5.

\subsubsection{QA/QC Requirements}

Quality Assurance/Quality Control (QA/QC) requirements for sediment coring activities in the IHP (Sect. 4.1.2) and WOL (Sect. 4.1.4) are addressed by reference to the following:

- Sample collection procedures. Specific WAG 2 field Standard Operating Procedures (SOPs) for sediment sample collection were developed and approved based on requirements specified in Table 3.2 of Sect. 3.3 and Sect. 2.5 (and Sect. 2.5.6) of the WAG 2 Field Sampling and Analysis Plan (DOE 1992a). As an integral part of preparations for field work, technical task leaders conduct an implementation task-level DQO process. The results of this process are documented and approved in a convenient short form, the Data Quality Objective Summary Form, for quick reference by personnel involved in field sampling, sample handling/tracking, and analytical laboratory coordination. The purpose is to preserve consistency and ensure validity with respect to governing project-level DQOs. 
- Analytical laboratory requirements. WAG 2 laboratory analytical methods for sediment samples are specified in Table 3.3 of Sect. 3.3 and Sect. 2.5 (and Sect. 2.5.7) of the WAG 2 Field Sampling and Analysis Plan (DOE 1992a). Additional analytical method requirements can be found in Appendix A of the WAG 2 Field Sampling and Analysis Plan-Responses to Comments (DOE 1992b).

- QC sample requirements. These requirements are discussed in Sect. 2.5.6.4 of the WAG 2 Field Sampling and Analysis Plan (DOE 1992a). Additional details are developed in the approved project-specific SOPs.

- Data review and assessment. This task is conducted as part of technical subject matter experts' data analysis, review, interpretation, and reporting activities. Data assessment is driven by the project-level DQO process.

- Quality assurance requirements. Project QA requirements are discussed in the WAG 2 Quality Assurance Plan (ORNL 1992b) and in Sect. 12 of the WAG 2 RI Plan (ORNL 1990).

\subsubsection{Erosion Rates Subtask}

Evaluation of erosion rates was initiated in FY 1993 to determine erosion rates for stream banks, stream channel bottoms, and upland hillslopes. This work will be continued in three activities:

- Stream channel erosion. Eight cross-section areas along WOC and Melton Branch have been surveyed regularly to evaluate changes in topography caused by erosion and deposition. In FY 1995 the surveying after large storms (about twice per year) will continue, and the data will be used to calculate erosion rates. The erosion study sites for both stream channel and stream bank erosion are shown in Fig. 4.

- Stream bank erosion. Erosion rates are determined from metal pins driven into the banks of a creek at baseflow water level and higher. After flood conditions are reached, the exposure of the pins is measured and compared with past measurements. In the past year the accumulated bank loss was $10 \mathrm{~cm}$ over 14 months (there were at least four large storms) at sites adjacent to the IHP, a heavily contaminated area.

- Hillslope erosion rates. Rates will be determined in nearby terrain of similar geological characteristics. Erosion data will support sediment transport modeling. Work will be conducted under a project outside of ORNL ER sponsorship, but the results will be beneficial for the WAG 2 RI analysis. Consequently, some limited resources will be assigned to coordination and reporting of results within the WAG 2 RI project.

\subsection{SEDIMENT TRANSPORT MODELING TASK}

The major quantities of contaminants in WAG 2 are associated with sediments and soils (particle-reactive contaminants that are strongly sorbed to silt and clay particles). These contaminants cause a potential risk to on-site workers via direct exposure to radiation and via indirect exposure through ingestion and/or inhalation. These contaminants also lead to a potential off-site risk via mobilization and transport during floods. The transport of particle- 


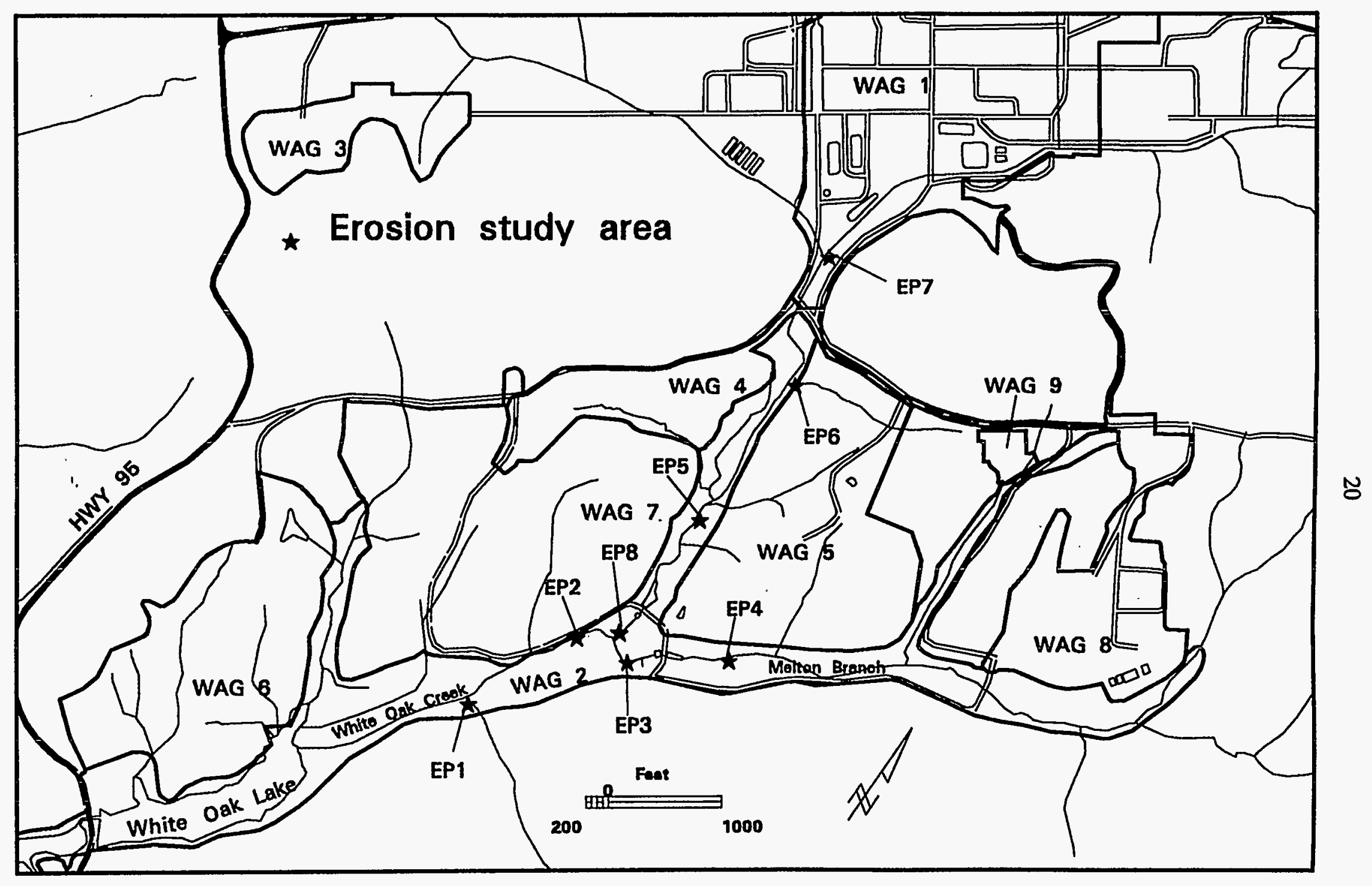

Fig. 4. Sediment erosion study sampling locations. 
reactive contaminants would result in deposition in the Clinch River/Watts Bar Reservoir system where the public could potentially have unacceptable exposures to the sediments or the sediments could be dredged and used in a manner leading to unacceptable exposures.

The on-site risk to workers is minimized by administrative controls and safe working procedures; therefore, it is not considered to be a driving factor for early remedial actions under current conditions. Initial assessments by the Clinch River RI project team suggest that mobilization and transport of contaminated sediments from WOC may not be a significant problem because the material discharged from WOC will be deposited in the deeper parts of Watts Bar Reservoir or will be diluted and transported over Watts Bar Dam with insignificant impact in either case. This initial, informal assessment needs to be rigorously assessed through computer simulation and documented.

The primary goal of this task is, therefore, to determine whether there is an unacceptable off-site risk to the public from contaminated soils and sediments that can potentially be mobilized during an extreme storm (up to the 100 -year event) or a reasonable sequence of extreme storms over a period of 20 years (after which the final WAG 2 closure is assumed to be in place). Meeting this goal requires computer simulation; historical records cannot be projected into the future because of environmental changes within WOC over the past 30 years. The secondary goal is to further develop the computer model so that it becomes a useful analytical tool to assist DOE in future prioritization and design of possible remediation activities. This goal will be achieved by identifying and evaluating scenarios for different remedial action alternatives (such as capping portions of WAGs).

To achieve these goals for FY 1995, the' main activity will be assessment through computer simulation. Other activities support this one by supplying the needed parameters and input data for the simulations. The soil and sediment task described in the preceding section also supports the modeling effort by supplying critically needed data on contaminant inventories within WAG 2. The emphasis in the proposed work is first on the analysis of existing data and second on performing the additional data collection but with reduced resources relative to past years. The proposed assessment will be documented in the WAG 2 Sediment Transport Summary Report due at the end of FY 1995.

\subsubsection{Sediment Transport Simulation Subtask}

The HSPF computer model was selected for sediment transport simulation (Fontaine 1991). It was developed for EPA for the purpose of simulating the movement of sedimentbound pesticides at watershed scales (EPA 1984). The HSPF has been calibrated to stream discharges in the WOC drainage system, and a sensitivity analysis has been completed. In FY 1995 these results will be documented, and the model will be parameterized and calibrated for sediment transport. A special version has been developed in the Environmental Sciences Division (ESD) at ORNL for the purpose of uncertainty analysis using Monte Carlo methods, and an uncertainty analysis will be performed. The watershed hydrology task (an activity within the concurrent ORNL Surface Water Program) will supply appropriate precipitation data sets to evaluate the effects of extreme storms. Simulation results of extreme storms will be evaluated with the aid of staff on the Clinch River project team in order to identify the resulting levels of risk. Should the results indicate unacceptable risks, then planning will commence that is focused on identifying removal actions to eliminate this risk. This possible follow-on activity will be coordinated with ER remedial design engineers, and it will include development of design alternatives and simple scenario evaluations. 


\subsubsection{Sediment Transport Data Package Subtask}

In FY 1993 and FY 1994, storm sampling at eight monitoring stations in the WOC watershed consisted of automatic collection to measure the sediment hydrograph over the entire discharge hydrograph during. a storm. Storm sampling also included manual sampling during the storm to evaluate the accuracy of the automatic sampling, which is potentially biased as a result of the fixed position of the sampling intake (i.e., the intake may collect too much sand or too much clay depending on position in the stream).

Data for three small storms in 1992 (return periods ranging from 1 to 2 years), two storms in 1993, and three storms in 1994 have been collected, processed, and partially analyzed. In the coming fiscal year, the data analysis will be completed. Sediment and contaminant discharges within the WOC system and discharge off-site, accuracy of measurements, and prevailing transport mechanisms, as revealed by the data, will be evaluated. The data package will be reviewed, placed in the project files, and sent to the Oak Ridge Environmental Information System (OREIS). Processed information and summary graphs will be published in the task report. Data files necessary for computer simulations will be generated.

\subsubsection{Sediment Transport Storm Sampling Subtask}

Collection of automatic and manual storm samples and subsequent processing proved to be extremely labor intensive and expensive, especially because a 3-month period had an exceptional series of floods: from December 1993 through the end of March 1994 there were four storms rated as $>5$-year return period. (It is evident that storm return periods need to be reevaluated, but that will be done as part of the watershed hydrology task in the ORNL Surface Water Program.) It became clear that too many samples were collected and that procedures for handling them and cleaning the sampling equipment thereafter was prohibitively expensive. Nevertheless, sediment and contaminant discharge data are needed during storms to (1) refine our conceptual model of how and where contaminants are mobilized and transported from the WOC watershed, (2) refine the computer model used to evaluate the effects of extreme storms, and (3) evaluate the accuracy of the compliance data collection system that collects composite samples at the major monitoring stations. The compliance data are not directly suitable for modeling purposes, but they represent the longterm record of contaminant discharges at ORNL.

The present DQOs for the WAG 2 RI require that all laboratory data be determined at the definitive level, and there is no provision for screening level data. Storm sampling should be considered screening level because the data are used to calibrate a model which, in turn, is used to generate results with a level of uncertainty that surpasses that expected in the laboratory analysis. Early in FY 1995 the project DQOs for sediment transport modeling and data collection will be reviewed. If changes are warranted then the project QA Plan (ORNL 1992b) and procedures for field, laboratory, and data validation work will be revised. Appropriate approvals will be sought prior to implementation.

Based on these considerations, the sampling effort proposed in FY 1995 consists of the following activities:

- Reassess the procedures for storm sample selection, laboratory analysis, and equipment maintenance. Reduce the number of sampling sites from eight to the five shown as solid 


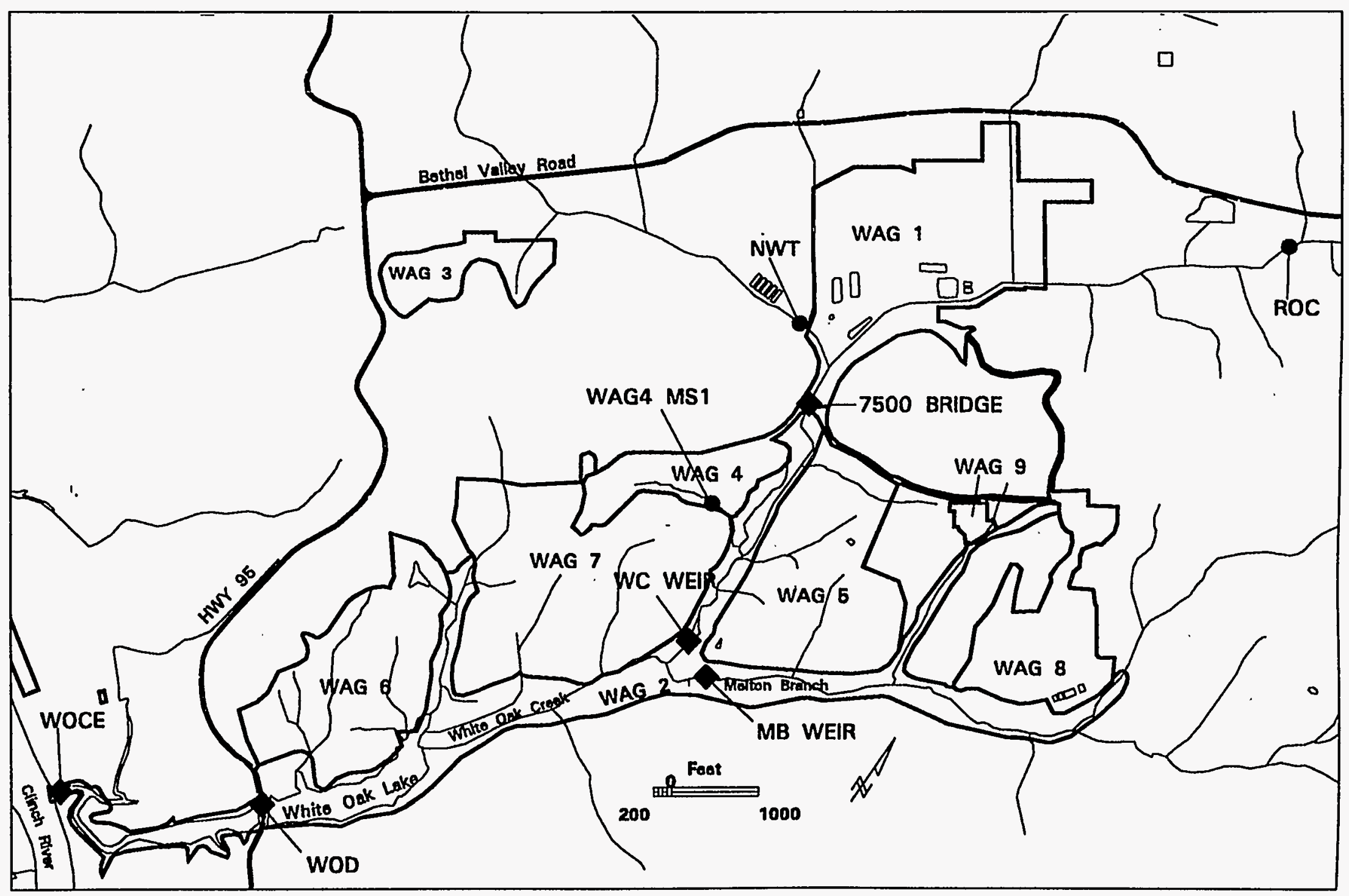

Fig. 5. Sampling sites for the sediment transport storm sampling subtask. 
black diamonds in Fig. 5. The goal will be that for any medium-sized storm $(1.25<t$ $<5$-year return period), the laboratory support will be limited to a 2-week effort of a task-staff person, a laboratory technician, and a student assistant. There will be manual sampling only for extreme flows that occur during normal working hours. This reassessment of procedures will be coordinated with the sediment transport modeler to ensure that data objectives are met, and it will be documented and approved in the first quarter of FY 1995.

- Through a coordinated effort of all program staff, determine the storm and discharge characteristics that warrant sample retrieval, selection, and analysis, thereby eliminating extra sample handling for inconsequential storms. Document and implement the results. Table 3 shows the size of storms that are candidates for intensive suspended sediment transport sampling. [In Table 3, the precipitation depth/recurrence values were obtained from a report generated by Bechtel National, Inc. (BNI 1993).] Precipitation recurrence interval is a poor method for selecting storms because peak discharges (that affect the sediment concentration and discharge) are not directly related to 24-hour precipitation. The objective will be to replace the storm depths with peak discharges in Table 3 and to use the discharge criteria for selecting sampling events.

Table 3. Storm classification for sediment storm sampling subtask

\begin{tabular}{ccc}
\hline Flood type & $\begin{array}{c}\text { Estimated rainfall } \\
\text { (in. per } 24 \text { h) }\end{array}$ & Probability \\
\hline Medium & $\begin{array}{c}2.6-4.4 \\
\text { (1.25- to 5-year return) }\end{array}$ & 0.6 \\
Large & $\begin{array}{c}>4.4 \\
(>5-y e a r \text { return })\end{array}$ & 0.2 \\
\hline
\end{tabular}

- Maintain the network of automatic storm samplers for the five key stations (shown as the solid black diamonds in Fig. 5). Collect data during possibly one to three small storm events and one large storm event. Thereafter, instrumentation and sample collection equipment will be maintained in an operational mode so that only storms exceeding those in the data base will be sampled and analyzed. Determine suspended sediment concentrations and ${ }^{137} \mathrm{Cs}$ concentration per sediment mass. For a limited number of subsamples, determine grain-size distributions by the pipette method or laser analysis, separate grain-size fractions by the column test method, and determine ${ }^{137} \mathrm{Cs}$ concentration per sediment mass per grain-size fraction. The latter data are used directly by the HSPF model. Data will be reported in data packages as described in the previous subtask.

Required analyses are summarized in Table 4. Analysis for the "expected" number of storms can be accomplished easily using available task resources, whereas handling the "maximum" number of storms or samples may require some reprioritization of resources, but the work load is not anticipated to be prohibitive. The probability values serve to 
show the likelihood that these floods will occur; therefore, all sampling within this task is speculative.

Table 4. Numbers of samples for radiological analysis for sediment transport storm sampling subtask

\begin{tabular}{ccccccccc}
\hline $\begin{array}{c}\text { Level of } \\
\text { effort }\end{array}$ & $\begin{array}{c}\text { Number } \\
\text { of storms }\end{array}$ & Probability & $\begin{array}{c}\text { Number } \\
\text { of sites }\end{array}$ & $\begin{array}{c}\text { Suspended } \\
\text { sediment } \\
\text { concentration }\end{array}$ & $\begin{array}{c}\text { Gamma } \\
\text { analysis/ } \\
\text { solids }\end{array}$ & $\begin{array}{c}\text { Gamma } \\
\text { analysis/ } \\
\text { filtrate }\end{array}$ & $\begin{array}{c}\text { Particie size } \\
\text { distribution }\end{array}$ & $\begin{array}{c}\text { Column } \\
\text { Test }\end{array}$ \\
\hline Expected $^{b}$ & 2 & 0.4 & 5 & 560 & 270 & 30 & 20 & 20 \\
Maximum $^{c}$ & 4 & 0.05 & 5 & 1520 & 600 & 67 & 50 & 40 \\
\hline
\end{tabular}

"Column Test is a newly developed and tested procedure to separate particle size fraction subsamples for contaminant analysis.

"Resources are allocated to meet the "expected" number of storms.

'Four storms includes three medium storms and one large storm ( $>5$-year return period). Project resources must be reallocated to perform the additional sampling.

- Define sediment transport storm sampling for Phase II of the WAG 2 RI. Even a lower level of effort of storm sampling will be maintained in the out-years after the HSPF model has been calibrated. Knowledge of the behavior of the sediment transport system can only be obtained by long-term data collection to ensure that the sediment transport in large but infrequent floods is measured. 


\section{BIOTA}

\subsection{BIOTA TASK}

Ecological data currently being collected for WAG 2 through ORNL's Biological Monitoring and Abatement Program (BMAP) address impacts on aquatic biota and the exposure of wildlife that feed from WOC and its floodplain (e.g., raccoons, mink, and kingfishers). However, current data do not address ecological effects of contaminated soils and sediment on resident biota. Therefore, data currently available for WAG 2 are not adequate to fully evaluate the ecological risk that contaminants at the site present to terrestrial and aquatic biota. To determine the magnitude of these risks and to determine if early actions may be needed, additional data are required. The tasks described here are intended to fill these data gaps. These tasks include completing the mink and kingfisher monitoring studies, performing toxicity tests with soils and sediments collected from WAG 2, determining contaminant residues in earthworms, evaluating the presence and abundance of shrews, obtaining baseline data to assess effects of contaminants on benthic invertebrates, and updating an existing mink-contaminant exposure model using WAG 2-specific data. This work will be fully integrated with the ORNL BMAP effort, with the Oak Ridge Reservation Environmental Restoration Monitoring and Assessment (ERMA) Program, and with biota studies on the source operable units in the WOC watershed.

These tasks do not provide the full set of ecological data specified for aquatic integrator operable units in the strategy for ecological risk' assessment developed by the FFA parties. However, given the limited goal of determining the need for early action, these tasks are believed adequate. They focus on highly sensitive receptors for both soil and sediment and use sample sizes adequate to characterize potentially severe effects that might prompt an early action. Any unresolved issues and data gaps can be addressed by the WAG 2 monitoring activities or the sampling and analyses for the WAG 2 RI/FS.

\subsubsection{Mink and Kingfisher Monitoring Subtask}

These tasks, begun in FY 1993, will be completed in FY 1995. To date, the feasibility of locating kingfisher burrows and obtaining samples has been demonstrated. Samples collected through the first three quarters of FY 1994 will be analyzed for metals and PCBs (see analyte list in Sect. 5.1.4) during the last quarter of FY 1994 and the first quarter of FY 1995. Analytical results will be incorporated into the fourth annual ERMA report. Results will also be incorporated into the WAG 2 ecological risk assessment (Sect. 5.2)

Monitoring of mink has been much less successful than the kingfisher monitoring efforts. After more than 3000 trap nights on streams around the Oak Ridge Reservation, only two mink have been captured. Samples from those mink have been submitted for analysis. One of those mink, captured on East Fork Poplar Creek, contained 104 ppm mercury in its fur. This concentration is substantially higher than concentrations previously associated with mercury toxicity in mink. In FY 1994, the task was expanded to include sampling of muskrats, a principal prey item for mink. Samples from 30 muskrats have been submitted for metals analysis (see analyte list in Sect. 5.1.4). In FY 1995, samples from muskrats will be submitted for PCB analysis, and samples from five mink found dead on the ORR and adjacent area roads will be submitted for metals and PCB analyses (see analyte list in Sect. 5.1.4). Results 
from mink and muskrat analyses will be incorporated into the fourth annual ERMA report. Results will also be included into the WAG 2 ecological risk assessment (Sect. 5.2).

\subsubsection{Soil Toxicity Testing Subtask}

Terrestrial soils, and the organisms that live upon or within soil, can be important receptors of contaminants. Soil-dwelling plants and animals can be adversely affected by contaminants in soils or can accumulate the contaminants and pass them on, in more concentrated form, to organisms that consume them. Because contaminated soils have the potential for impacting ecological communities, soil toxicity testing is gaining acceptance as an important and necessary component of ecological risk assessments. Standardized methods for assessing soil toxicity are currently being developed and validated. EPA has published guidelines for screening soils for toxicity to earthworms (Eisenia foetida) (Greene et al. 1988), and standardized soil toxicity tests with vascular plants are being developed and validated for use in ecological risk assessments (DOE 1993b).

\subsubsection{Sampling location and frequency}

Soil samples for toxicity testing will be collected from 12 locations by WAG 2 sampling personnel. Three of the samples will be from reference sites. These sites will be selected based on soil characteristics similar to those in the WAG 2 area, except for the presence of known contaminants. The remaining nine samples will be collected from locations in the WOC and Melton Branch floodplain where contaminant concentrations are elevated or potentially elevated. The specific sampling sites will be selected after consideration of soil chemistry data and data collected from Phase I soil and sediment coring and analysis. The sites will be sampled and tested once during the spring of 1995.

\subsubsection{Sample collection and analysis}

One 2-L sample volume will be collected from each designated sampling site. In the field, large gravel and debris will be removed by sieving the soil through a coarse (e.g., 0.5-cm) sieve. The sieved samples will then be conveyed to ESD for soil toxicity testing in the Aquatic Ecology Laboratory in Building 1504. Whole soil toxicity of the samples will be estimated by testing with earthworms (Eisenia foetida) and a small flowering plant (Arabidopsis thallania). These two species were used recently for soil toxicity testing in the Portsmouth Gaseous Diffusion Plant (PORTS) Baseline Ecological Risk Assessment (BERA) (DOE 1993b). The $E$. foetida test uses as endpoints survival, growth, and reproduction. The $A$. thallania test uses as endpoints germination and growth. SOPs for tests with both species were developed and validated for use in the PORTS BERA, and these will be followed for tests of the WAG 2 samples.

Portions of each of the soil samples will be analyzed for $\mathrm{pH}$, organic matter content, and cation exchange capacity so that responses of $E$. foetida and $A$. thallania can be related statistically to these soil parameters. Contaminant analyses (radionuclide, inorganic, $\mathrm{PCB} /$ pesticide, and polycyclic aromatic hydrocarbon) will be performed on WAG 2 floodplain soil as part of the soil characterization assessment subtask. Contaminant data shall also be utilized to assess responses of $E$. foetida and $A$. thallania. Soil samples from many of the WAG 2 sites are expected to be contaminated with radionuclides. Thus the soil toxicity and characterization activities for this task are contingent on the availability of adequate health, 
safety, and disposal procedures, as well as soil handling and testing facilities as deemed necessary by the task's principal investigator.

\subsubsection{Sediment Toxicity Testing Subtask}

Surface sediments are recognized as ecologically and toxicologically significant in their role as both a habitat for various benthic organisms serving as an important component of the aquatic food web and a sink for many metal and hydrophobic organic contaminants. Because contaminated sediments have the potential for impact on ecological systems, sediment toxicity testing, on both whole sediment and sediment pore water, is gaining acceptance as an important and necessary component of ecological risk assessments. Standardized methods for assessing freshwater sediment toxicity are currently being developed. EPA is considering the use of Chironomus tentans, Hyalella azteca, and Lumbriculus variegatus as standard whole freshwater sediment toxicity test organisms. As of yet, the EPA has not provided guidance on pore water toxicity testing. Many investigators, however, have used Daphnia magna as a test organism for both pore water toxicity and sediment elutriate toxicity tests. This organism is an epibenthic organism that is potentially sensitive to contaminants leached from sediments into the overlying water column. Regardless of species selection, a major issue with respect to sediment toxicity evaluations is the relevance of data obtained from the laboratory tests on sediment samples collected and removed from field sites to actual, in situ toxicity. The alteration of chemical and physical properties of a sediment sample incurred during sampling/removal and shipping can modify significantly the partitioning and speciation of associated contaminants and therefore its toxicity. Redox gradients, $\mathrm{pH}$, particle size, and organic carbon are all important parameters affected by the sampling and handling of sediment samples. Extraction of pore water (e.g., by centrifugation) changes the original sample chemistry even further.

\subsubsection{Sampling location and frequency}

Sediment samples to be used in the sediment toxicity tests will be collected at a total of seven sites by WAG 2 sampling personnel: two sites in Melton Branch, two sites in WOC, one site in the upper portion of WOL, one site in WOL, and one reference site at a location yet to be determined. The seven sites will be sampled and tested once in early spring of 1995 . Specific sampling locations will be determined at a later date.

\subsubsection{Sample collection and analysis}

One 2-L sample volume will be collected from one location at each designated sampling site. In the field, large gravel and debris will be removed from whole sediment samples, homogenized, and placed into sampling containers prior to being shipped to the ESD Aquatic Toxicology Laboratory (ATL) for analysis. Whole sediment toxicity will be evaluated using Chironomus tentans (survival and growth endpoints; ESD ATL Quality Assurance Program SOP-35) and Daphnia magna (survival and reproduction endpoints; ESD ATL Quality Assurance Program SOP-22). Both procedures are based on guidelines outlined in the American Society for Testing and Materials (ASTM) Standard Guide for Conducting Sediment Toxicity Tests with Freshwater Invertebrates (E 1383-90). No pore water extraction or toxicity testing will be done. Each sample will also be analyzed for moisture content, $\mathrm{pH}$, particle size distribution, and organic content using ASTM or Methods of Soil Analysis procedures. All sediment toxicity testing and characterization activities for this project are contingent on the availability of adequate health, safety, and disposal procedures and facilities as deemed 
necessary by the ESD ATL. Disposal of tested sediment samples and associated rinse water will be handled by the WAG 2 sampling group. Testing activities are also contingent on the location of an adequate reference sediment.

\subsubsection{Earthworm Sampling and Analysis Subtask}

To determine if soil contamination is bioavailable and may be transferred from soil to soil invertebrates, contaminant body burdens will be determined for earthworms collected from the IHP, above WOL, and Raccoon Creek or Bearden Creek (reference) areas. These data may then be used to determine ecological risks to vermivores, such as shrews.

Earthworms will be collected under controlled conditions using a mustard solution (Gunn 1992) as an expellant as described by Bechtel (BNI 1994). This technique will be used because it is nonintrusive, minimizes exposure of personnel to contaminants, and is not as labor intensive as hand sorting. Also, this method provides a consistent sample from a specified area, which permits addressing the effects on worms as well as the things that consume worms. Three sampling sites, approximately $30 \mathrm{~m}$ apart, will be established in each area (WAG 2 and reference) chosen on the basis of soil contaminant screening analyses (i.e., for radionuclides). This plan is based on the assumption that all contaminant concentrations are correlated with radionuclide levels. All worms collected from each sampling site will be combined into one composite sample (for a total of three from each area). Samples will be taken by forcing a 50 - by $50-\mathrm{cm}$ stainless steel frame approximately $10 \mathrm{~cm}$ into the soil. Three to $6 \mathrm{~L}$ of a mustard and water suspension will then be slowly applied to the soil surface within the frame with a watering can (to obtain even spread and minimal ponding). Surfacing earthworms will be collected with forceps until 'no additional worms emerge from the soil (approximately 20 to $25 \mathrm{~min}$ ). Multiple locations will be sampled at each sampling site until a total of approximately $450 \mathrm{~g}$ (wet weight) of worms is collected from each sampling site.

Upon collection, each worm will be rinsed in the field with deionized water (to remove soil and expellant), placed in a sealed petri dish, and set in a cooler. It is essential that all worms be kept moist, intact, alive, and handled at a minimum. Parameters recorded for each earthworm will include sample location, sample site, date collected, wet weight (to be measured in the laboratory), presence of clitellum (girdle), and general physical condition including overt signs of lesions or other abnormalities. In addition, a running total of earthworms collected since the time expellent was added (in 2-min intervals) should be recorded.

All worms will be maintained in the laboratory for 3 days to allow voiding of intestinal tract contents. Depurate (intestinal tract contents) collected from the earthworms will be composited by each of the five sample sites per area. All samples (worm and depurate) will be analyzed for the following contaminants. This contaminant list may be modified as future data become available.

- inorganics

- $\quad \mathrm{Ag}, \mathrm{As}, \mathrm{Ba}, \mathrm{Be}, \mathrm{B}, \mathrm{Cd}, \mathrm{Co}, \mathrm{Cr}, \mathrm{Cu}, \mathrm{F}, \mathrm{Li}, \mathrm{Mo}, \mathrm{Ni}, \mathrm{Pb}, \mathrm{Sb}, \mathrm{Se}, \mathrm{Sr}, \mathrm{Tl}, \mathrm{V}$, and $\mathrm{Zn}$ (by inductively coupled plasma/mass spectroscopy, Method SW846-6020)

- Hg (by cold vapor atomic absorption, Method SW846-7471) 
- organics

- PCBs/pesticides (by capillary column gas chromatograph/electron capture, Method SW846-8080)

- polycyclic aromatic hydrocarbons (by Method SW846-8310)

The optimum dry weights required to meet detection limits for risk assessment are the same for both earthworms and depurate. These values are 2 to $3 \mathrm{~g}$ for inorganic analysis and approximately $10 \mathrm{~g}$ for organic analysis for a total of 12 to $13 \mathrm{~g}$ (dry weight) for worm weight and depurate volume. This requirement will be met with the $450 \mathrm{~g}$ wet weight of fresh earthworms with suitable allowance for conversion from wet weight to dry weight basis for worms and depurate.

\subsubsection{Shrew Sampling and Analysis Subtask}

Shrews, as vermivores, may be adversely affected by soil contaminants accumulated by their prey, soil invertebrates (earthworms). If comparisons of estimated contaminant exposures for shrews (derived from earthworm body burden data) to toxicological benchmarks suggest potential adverse effects, field data (presence, abundance, and condition of shrews in WAG 2) will be needed to determine validity of the results and determine if shrews are affected.

The presence and abundance of shrews in WAG 2 will be surveyed by using pitfall traps and drift fences (Call 1986). Four 100-m transects will be established in each of the three sampling areas (the IHP and above WOL in WAG 2 and a reference site along either Bearden Creek or Raccoon Creek). Two transects will be located at each sampling site. Each transect will consist of 21 pitfall traps (plastic containers, 0.5 to $1 \mathrm{~L}$ in size, buried in the ground so that their tops are flush with the surface) located about $10 \mathrm{~m}$ apart and arranged in a zigzag pattern. Drift fence (wire mesh approximately $20 \mathrm{~cm}$ high and buried approximately $4 \mathrm{~cm}$ into the ground) will run between adjacent pitfall traps.

After installation of the pitfall traps, they will be covered with small boards for about 10 days to allow resident animals to become accustomed to their presence (Call 1986). After this 10-day period, the boards will be removed and each area will be sampled for 10 days. Traps will be checked each morning. Age, sex, body measurements (weight, tail length, and head/body length) and species of all small mammals caught will be recorded.

\subsubsection{Benthic Invertebrate Sampling Subtask}

Benthic macroinvertebrate samples will be collected from 10 sites including 6 within WAG 2 and 4 appropriate reference sites. The sampling sites in WAG 2 will include the depositional pond areas behind two weirs each on Melton Branch (one site near the mouth of the stream and one site $\sim 200 \mathrm{~m}$ downstream of the High Flux Isotope Reactor discharge tributary) and WOC (one site just upstream of the stream's confluence with Melton Branch and one site just downstream of Melton Valley Road), and one site each in upper WOL and in mid/lower WOL. The reference sites will include depositional areas behind weirs on two relatively unimpacted streams located on or adjacent to the Oak Ridge Reservation, and two small, relatively unimpacted ponds/reservoirs also located on or adjacent to the Oak Ridge Reservation; the exact location of each reference site will be designated prior to any collection. A single collection will be made in mid-October/mid-November 1994. A total of five replicates will be taken from each site. 
Selection of the benthic macroinvertebrate sampling sites will follow the procedures developed by Smith and Wojtowicz (1992). Quantification of benthic macroinvertebrates at each study site will use a hand-operated coring device, based on procedures established in previous studies (Williams and Hynes 1974, Godbout and Hynes 1982, Strommer and Smock 1989). Briefly, replicate core samples will be removed from three randomly selected transect cells at each sampling site (Smith and Wojtowicz 1992) and placed in labeled containers for transport to the laboratory. An appropriate sample preservation technique will be employed depending on the type of analysis needed (each sample analyzed whole or sectioned for depth analysis). Specifically, organisms will be removed from the substrate and sample debris with the aid of a $2 x$ illuminated magnifying lens, identified to the lowest practical taxon, and enumerated.

\subsection{ECOLOGICAL RISK ASSESSMENT TASK}

Although the interim ecological risk assessment for WAG 2 will not be completed until early FY 1996, efforts during FY 1995 will be required to begin the assessment process and to ensure that the sampling and analysis activities generate useful data. The ecological risk assessments for WAG 2 will be performed using the strategy developed by the FFA parties (Suter et al. 1994). In that strategy, aquatic integrator units like WAG 2 are assessed for three reasons: (1) to determine the need to remediate contaminated materials in the operable unit because of the risks posed to ecological endpoints associated with the operable unit, (2) to determine the need for remediation of source operable units within the watershed, and (3) to determine the contribution of the operable unit to risks to reservation-scale ecological endpoints. Hence, WAG 2 must be characterized in relation to other operable units, as well as being characterized in terms of the risks posed by in situ contamination. The strategy calls for using a weight-of-evidence method that includes data concerning the biological condition of the system, as well as the contaminant analyses of abiotic media used in the human health risk assessment. All available and appropriate data will be incorporated in this effort.

MacIntosh et al. (1992) developed off-site contaminant exposure models to evaluate the risk to mink and great blue herons from mercury and PCBs in the Watts Bar-Clinch River system. To evaluate the exposure and potential effects of PCBs and mercury to mink in WAG 2, the model will be updated using site-specific data (e.g., from WAG 2). These data will include whole-body fish body burdens, muskrat contaminant body burdens, and contaminant concentrations in sediment and water from WAG 2. 


\section{GROUNDWATER}

Environmental media in WAG 2 function as integrators of contaminant fluxes passing through the lower WOC hydrologic system from adjacent WAGs to discharge into the Clinch River. Surface water and groundwater are the principal components of this system that are capable of transmitting contaminants. Groundwater flow and contaminant transport in the groundwater in the WAG 2 floodplain areas are observed to be significant pathways for contaminant fluxes from the source WAGs to the surface water system of WAG 2.

The long-term requirements of groundwater investigation with respect to WAG 2 that include groundwater flow considerations will be transitioned into the Area Groundwater Program as part of a restructuring effort. Short-term requirements for information and data on contamination of groundwater will be addressed in the FY 1995 WAG 2 RI Work Plan and will center on completion of RI Phase I activities, including the following. Data will be made available to potential users through OREIS.

A data summary report will be produced that includes complete analysis and interpretation of relevant WAG 2 groundwater data to date on contamination characteristics and extent. This report will include interpretation of relevant aspects of the groundwater flow system and the nature and extent of groundwater contamination in WAG 2 using data from WAG investigations, as well as data from WAG 5 investigations and ORNL compliance program data. The report will summarize available data, show graphically the distribution of detected contaminants in groundwater in WAG 2, provide a screening-level risk assessment based on the available groundwater contaminant data, and identify additional activities that need to be addressed by continuing efforts of the ORNL Area Groundwater Program and/or adjacent contaminant source WAG activities. 


\section{RISK ASSESSMENT}

The WAG 2 DQO Workshop meeting with the regulators addressed potential human health risk concerns within WAG 2 with respect to potential to create significant off-site sediment releases in the Clinch River and the magnitude of associated effects. It was reiterated that remedial action and a complete baseline risk assessment will be conducted after the remediation of upstream source WAGs.

Human health risk assessment has been used to support WAG 2 activities for two primary reasons: (1) to assist in communicating data results to regulators and (2) to establish a foundation for determining whether an early action is necessary for WAG 2 . Human health risk assessment activities that are focused on the need for determining whether an early action is necessary for WAG 2 will complete Phase I activities. The use of risk assessment to interpret data and communicate results to regulators will transfer to the Surface Water and Groundwater programs. To assist in determining the need for an early action, information provided by FY 1995 field efforts will be used to calculate human health risk to indicate the need for interim corrective measures, analysis of remedial alternatives, and updating the conceptual model that directs additional sampling and analysis efforts. Risk modeling and assessment activities will then provide the mechanism for conducting a comprehensive assessment of the effectiveness of proposed remedial alternatives.

WAG 2 Phase I human health risk activities for FY 1995 will assist in evaluating the potential for events that could cause a health risk of concern to off-site populations prior to final remediation of WAG 2 . The assessment will be focused on utilizing the results of sediment modeling for releases to the Clinch River. The events that have been identified to potentially result in an off-site risk stem from the possibility of an extreme storm event mobilizing enough ${ }^{137} \mathrm{Cs}$-contaminated sediment to create a risk to receptors downstream of WOD through deposition in the Clinch River and the possible increase in the potential for sediment mobilization from WOL over time due to sediment deposition and the filling of WOL. The sediment transport modeling task within WAG 2 produces model simulations to quantify current transport of contaminants and predict the amount released during erosion events. The results of the modeling proposed for the modeling task will be used in the human health risk assessment to determine whether potential contaminant levels are of sufficient magnitude to necessitate an early action focused on the WAG $2{ }^{137} \mathrm{Cs}$ sediment source term. If action is necessary, then the results of different proposed remedial alternatives will be evaluated by using similar modeling and risk assessment efforts to assist in evaluating the effectiveness of proposed remedial alternatives.

The precedence for determining whether off-site action is necessary, based on current and potential future land use conditions, has been established through the DQO process and the formation of risk assessment scenarios for the Clinch River RI. Selected pathways relevant to ${ }^{137} \mathrm{Cs}$ contamination in sediment from these scenarios will be used to calculate the potential risk from a WAG 2 sediment release. The scenarios considered for the risk assessment are based on current land use conditions, with the exception of dredging. Lower Watts Bar Reservoir water levels typically drop in October for flood control purposes and remain at this level until April. During this time, sediments in shallow water are exposed in areas utilized by the public for recreational purposes. The pathways to be calculated for current recreational use conditions include external exposure, sediment ingestion, dermal contact, inhalation of 
air containing sediment-derived particulates, and fish consumption. Dredging of sediments is controlled by the U.S. Army Corps of Engineers and the Tennessee Valley Authority and will not be permitted without consideration of health hazards. However, dredging activities are considered in the Clinch River RI risk assessment to address the possibility that uncontrolled disposal of dredge spoils might occur. Direct exposure pathways for the dredging scenario include external exposure, ingestion of dredged sediment, dermal contact with the sediment, and inhalation of air containing sediment-derived particulates. Indirect exposures can also occur through the ingestion of vegetables, beef, and milk produced on the dredged sediment. If it is determined that the dredging of sediments is not a consideration for evaluating the need for an early action in WAG 2, then a risk assessment based solely on current recreational land use conditions will be evaluated. 


\section{TECHNICAL INTEGRATION}

This task will provide an interface with the ORNL ER Program Technical Integration Group, with other WAG managers, and between individual RI tasks in this project to ensure effective information transfer. Requirements include completing planned Phase I RI activities in FY 1995, initiating a limited number of Phase II RI activities in FY 1995, and performing specific tasking directed by the DQO process and regulator inputs.

As an example of cooperative interaction, WAG 2 is in the process of establishing structures for exchanging data over the next several years beginning in FY 1995 with project team members from other WAGs on potential radionuclide contaminants of concern and their associated fluxes that may be attributable to sources lying upslope or upstream of the WAG 2 floodplain and WOL. This will require technical integration involvement and follow-up to maximize the benefits to be realized by WAG 2 as well as other WAG teams. 


\section{INFORMATION MANAGEMENT AND ANALYSIS}

This task includes providing project-level data management, analytical laboratory services coordination and data validation, consistency with QA/QC requirements, statistical analysis and data assessment, and records management of data record files and meeting ER indexing/archiving requirements. Effective data management in this project is centered on ensuring accuracy, completeness, and integrity of project data and maintenance in a readily available data base for prospective users.

Data management activities for FY 1995 continue to include acquiring data from field measurements, acquiring data from laboratory analyses of environmental samples, storing output from simulation models and other sources, providing data to and acquiring data from OREIS, and compiling all pertinent historical data. Ongoing assessments of data quality are being conducted by data management and data validation staff to determine usability. Data management is important to ensure that the data are accurately entered into the data base and made available to the project in a timely manner, without the introduction of additional uncertainty from data entry and processing activities. Data management is an important component of all tasks in the WAG 2 RI project and will serve as the link for sharing of data within the project, as well as exchanging information outside the project through OREIS. All data will be available to FFA managers through OREIS.

This task also supports an analytical services coordinator to interface with the Analytical Projects Office, prepare statements of work for analytical laboratories, conduct laboratory readiness reviews, coordinate the performance evaluation program, and issue nonconformances, when necessary.

The data management team is the link for maps generated by the Geographic Information System (GIS) and statistical analysis of the data. The personal computer-based mapping system (MAPINFO) allows team members to generate maps and analyze data in a spatial format. A Sun workstation and ARC Info software increase the capacity to manage, manipulate, and store the large GIS data sets generated in this project.

The data validation team includes the analytical services coordinator and coordinates efforts with data management to ensure the inclusion of validated, qualified analytical data in the data base. The data validation team develops and revises SOPs pertinent to analytical validation activities, oversees the comprehensive data validation process, verifies laboratory compliance with the WAG 2 statements of work, performs sample tracking, validates data packages, and transmits data validation reports to data management for inclusion into the data base. Implementation of a bar coding system for sample identification and tracking facilitates data transfer and enhances data quality.

A project QA/QC specialist coordinates the development, review, and approval of all field, laboratory, and administrative procedures. The QA/QC specialist is responsible for ensuring that all personnel are trained as needed, that records are kept, and that the procedures in the WAG 2 QA Plan are implemented. The QA/QC specialist conducts periodic field and laboratory surveillances on selected tasks and reports these findings to the project manager/deputy project manager. 
The records management coordinator ensures the timely and accurate transmittal and incorporation of project record files into the WAG 2 document management system for indexing and archiving. 


\section{REFERENCES}

BNI (Bechtel National, Inc.). 1993. Analysis of the Oak Ridge Hourly Rainfall Record for Storm Characterization for WAG 5. Technical Bulletin O5-TB-014. Bechtel National, Inc., Oak Ridge, Tennessee.

BNI (Bechtel National, Inc.). 1994. Field Work Guide for WAG 5 Earthworm Sampling. Document 19118-05-WG-21. Bechtel National, Inc., Oak Ridge, Tennessee.

Call, M. W. 1986. Rodents and insectivores. In A. Y. Cooperrider, R. J. Boyd, and H. R. Stuart, eds., Inventory and Monitoring of Wildlife Habitat. pp. 429-452. U.S.D.I. Bureau of Land Management Service Center, Denver, Colorado.

DOE (U.S. Department of Energy). 1992a. Field Sampling and Analysis Plan for the Remedial Investigation of Waste Area Grouping 2 at the Oak Ridge National Laboratory, Oak Ridge, Tennessee. DOE/OR-1070\&D1. Oak Ridge National Laboratory, Oak Ridge, Tennessee.

DOE (U.S. Department of Energy). 1992b. Field Sampling and Analysis Plan for the Remedial Investigation of Waste Area Grouping 2 at Oak Ridge National Laboratory, Oak Ridge, Tennessee-Responses to Comments. DOE/OR-1070\&D2. Oak Ridge National Laboratory, Oak Ridge, Tennessee.

DOE (U.S. Department of Energy). 1993a. Phase I Remedial Investigation Report of Waste Area Grouping 2 at the Oak Ridge National Laboratory, Oak Ridge, Tennessee. DOE/OR/011179\&D1. Oak Ridge National Laboratory, Oak Ridge, Tennessee.

DOE (U.S. Department of Energy). 1993b. Baseline Ecological Risk Assessment Workplan for the Portsmouth Gaseous Diffusion Plant, Piketon, Ohio. DOE/OR/12-1163\&D3, POEF/ER4500-D3. Oak Ridge National Laboratory, Oak Ridge, Tennessee.

EPA (U.S. Environmental Protection Agency). 1984. Hydrologic Simulation Program-FORTRAN (HSPF)-User's Manual for Release 8.0. Environmental Protection Agency, Athens, Georgia.

Fontaine, T. A. 1991. Monitoring and Modeling Contaminated Sediment Transport in the White Oak Creek Watershed. ORNL/ER-65. Oak Ridge National Laboratory, Oak Ridge, Tennessee.

Godbout, L., and H. B. N. Hynes. 1982. The three dimensional distribution of the fauna in a single riffle in a stream in Ontario. Hydrobiologia 97:87-96.

Greene, J. C., C. L. Bartels, W. J. Warren-Hicks, B. R. Parkhurst, G. L. Linder, S. A. Peterson, and W. E. Miller. 1988. Protocols for Short Term Toxicity Screening of Hazardous Waste Sites. EPA 600/3-88/029. Corvallis Environmental Research Laboratory, Corvallis, Oregon.

Gunn, A. 1992. The use of mustard to estimate earthworm populations. Pedobiologia 36: 65-67. 
MacIntosh, D. L., G. W. Suter II, and F. O. Hoffman. 1992. Model of the PCB and Mercury Exposure of Mink and Great Blue Heron Inhabiting the Off-site Environment Downstream from the U.S. Department of Energy Oak Ridge Reservation. ORNL/ER-90. Oak Ridge National Laboratory, Oak Ridge, Tennessee.

ORNL (Oak Ridge National Laboratory). 1990. Remedial Investigation Plan for Waste Area Grouping 2 at Oak Ridge National Laboratory, Oak Ridge, Tennessee. ES/ER-14\&D1. Environmental Restoration Program. Oak Ridge National Laboratory, Oak Ridge, Tennessee.

ORNL (Oak Ridge National Laboratory). 1992a. D. K. Solomon, G. K. Moore, L. E. Toran, R. B. Dreier, and W. M. McMaster. Status Report: A Hydrologic Framework for the Oak Ridge Reservation. ORNL/TM-12026. Oak Ridge National Laboratory, Oak Ridge, Tennessee.

ORNL (Oak Ridge National Laboratory). 1992b. G. P. Atwood and D. E. Miller. Quality Assurance Plan for the Remedial Investigation of Waste Area Grouping 2 at Oak Ridge National Laboratory, Oak Ridge, Tennessee. ORNL/ER-134 (Rev. 0). Oak Ridge National Laboratory, Oak Ridge, Tennessee.

ORNL (Oak Ridge National Laboratory). 1993a. T. J. Newsom, S. Blair, D. S. Hicks, and R. H. Ketelle. Source Areas Investigation Plan and Recommendation for Removal Actions at Waste Area Grouping 5 at Oak Ridge National Laboratory. ORNL/ER-165. Oak Ridge National Laboratory, Oak Ridge, Tennessee.

ORNL (Oak Ridge National Laboratory). 1993b. G. H. Cofer, V. L. Holt, and G. W. Roupe. Health and Safety Plan for the Remedial Investigation and Site Investigation of Waste Area Grouping 2 at the Oak Ridge National Laboratory, Oak Ridge, Tennessee. ORNL/ER-169. Oak Ridge National Laboratory, Oak Ridge, Tennessee.

Smith, J. G., and J. A. Wojtowicz. 1992. Biological Monitoring and Abatement Program benthic macroinvertebrate monitoring project sample collection and storage QA plan. ORNL/QAP-x-90ES-068. Environmental Sciences Division, Oak Ridge National Laboratory, Oak Ridge, Tennessee.

Strommer, J. L., and L. A. Smock. 1989. Vertical distribution and abundance of invertebrates within the sandy substrate of a low-gradient headwater stream. Freshwat. Biol 22:263-274.

Suter II, G. W., B. E. Sample, D. S. Jones, and T. L. Ashwood. 1994. Approach and Strategy for Performing Ecological Risk Assessments for the Department of Energy's Oak Ridge Reservation: 1994 Revision. ES/ER/TM-33/R1. Oak Ridge National Laboratory, Oak Ridge, Tennessee.

Williams, D. D., and H. B. N. Hynes. 1974. The occurrence of benthos deep in the substratum of a stream. Freshwat. Biol. 4:233-256. 